\title{
ANALISIS NILAI EKONOMI HUTAN MANGROVE DI KABUPATEN MUNA (Studi Kasus di Desa Labone Kecamatan Lasalepa dan Desa Wabintingi Kecamatan Lohia)
}

\author{
Abdul Rakhfid dan Rochmady \\ Staf Pengajar Prodi Budidaya STIP Wuna Raha, e-mail: kampo.mokesano@gmail.com
}

\begin{abstract}
ABSTRAK
Penelitian dilaksanakan bulan Juni-Desember 2013 di Desa Labone, Kecamatan Lasalepa dan Desa Wabintingi, Kecamatan Lohia, Kabupaten Muna tentang nilai ekonomi hutan dengan pendekatan nilai pasar menggunakan instrumen kuisioner dan wawancara mendalam. Data pengukuran vegetasi hutan dan nilai ekonomi dianalisis secara deskriptif. Hasil analisis menunjukkan nilai penutupan 18,347\%, 27,932\% dan 3,766\% (Ci<50\%). Hutan mangrove di Desa Wabintingi, nilai penutupan 104,909\%, 25,480\% dan 37,691 (Ci>75\%). Kondisi hutan mangrove Desa Wabintingi lebih baik dibanding hutan mangrove Desa Labone. Jenis pemanfaatan sumberdaya hutan mangrove di Desa Labone yakni penambangan pasir, pengambilan kayu bakar komersial, pengrajin atap nipa, penangkapan kepiting, ikan dan pengumpulan kerang-kerangan. Sementara di Desa Wabintingi yakni pengrajin atap daun nipa, penangkapan kepiting, udang, ikan, dan pengumpulan kepiting. Manfaat tidak langsung berupa penjaga abrasi pantai, siklus makanan dan penyedia bahan organik, dan sebagai penyerap karbon. Nilai ekonomi Desa Labone mencapai Rp.131.076.911,- per hektar per tahun atau sebesar Rp.2.836.335.023,- per tahun dengan sumbangan terbesar bersumber dari manfaat tidak langsung sebesar $95,10 \%$, manfaat pilihan 2,88\%, manfaat keberadaan 1,57\% dan manfaat langsung 0,45\%. Sementara nilai ekonomi Desa Wabintingi mencapai Rp.135.116.100,- per hektar per tahun, dengan sumbangan tersbesar bersumber dari manfaat langsung aktual 63,57\%, manfaat tidak langsung 34,55\%, manfaat keberadaan 1,78\% dan manfaat pilihan $0,10 \%$.
\end{abstract}

Kata Kunci: Nilai ekonomi, hutan mangrove, Vegetasi hutan dan Kabupaten Muna.

\section{PENDAHULUAN}

1.1. Latar Belakang

Hutan mangrove memiliki peranan cukup penting yakni sebagai sumber mata pencaharian, karena dapat menghasilkan berbagai produk bernilai ekonomi terutama sebagai penghasil produk kayu, ikan, kepiting, kerang dan lain-lain, serta sebagai wahana rekreasi dan wisata alam maupun pendidikan. Dewasa ini, peranan mangrove bagi lingkungan sekitarnya dirasakan semakin besar, oleh karena adanya berbagai dampak merugikan yang dirasakan diberbagai tempat akibat hilangnya hutan mangrove, seperti tsunami, intrusi air laut, dan lain-lain.
Sebagai sumberdaya alam yang memiliki potensi ekonomi, pemanfaatan hutan mangrove perlu dilakukan sebaik-baiknya sehingga dapat memberikan manfaat bagi kesejahteraan dengan tetap memperhatikan kelestarian, sehingga manfaat yang diperolehpun dapat berkelanjutan (sustainable). Namun, terkadang pemanfaatan tersebut tidak memperhatikan batas-batas kemampuan atau daya dukung lingkungan baik secara biologis, fisik, ekologis maupun secara ekonomis, sehingga menimbulkan dampak yang merugikan masyarakat. Masalah mendasar dalam pengelolaan sumberdaya alam menurut Fauzi, A. (2004) adalah upaya mengelolah sumberdaya alam tersebut agar menghasilkan manfaat yang 


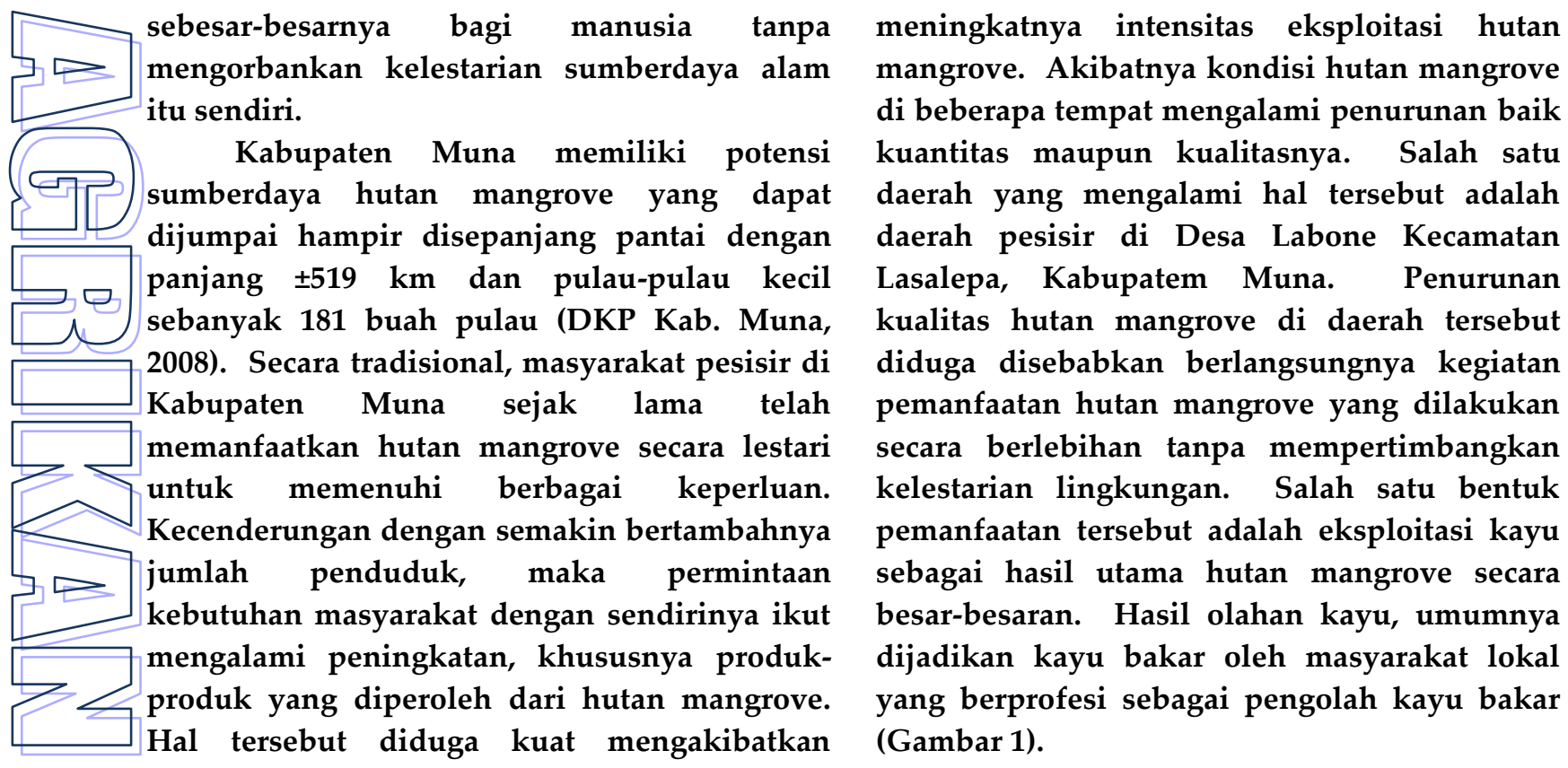
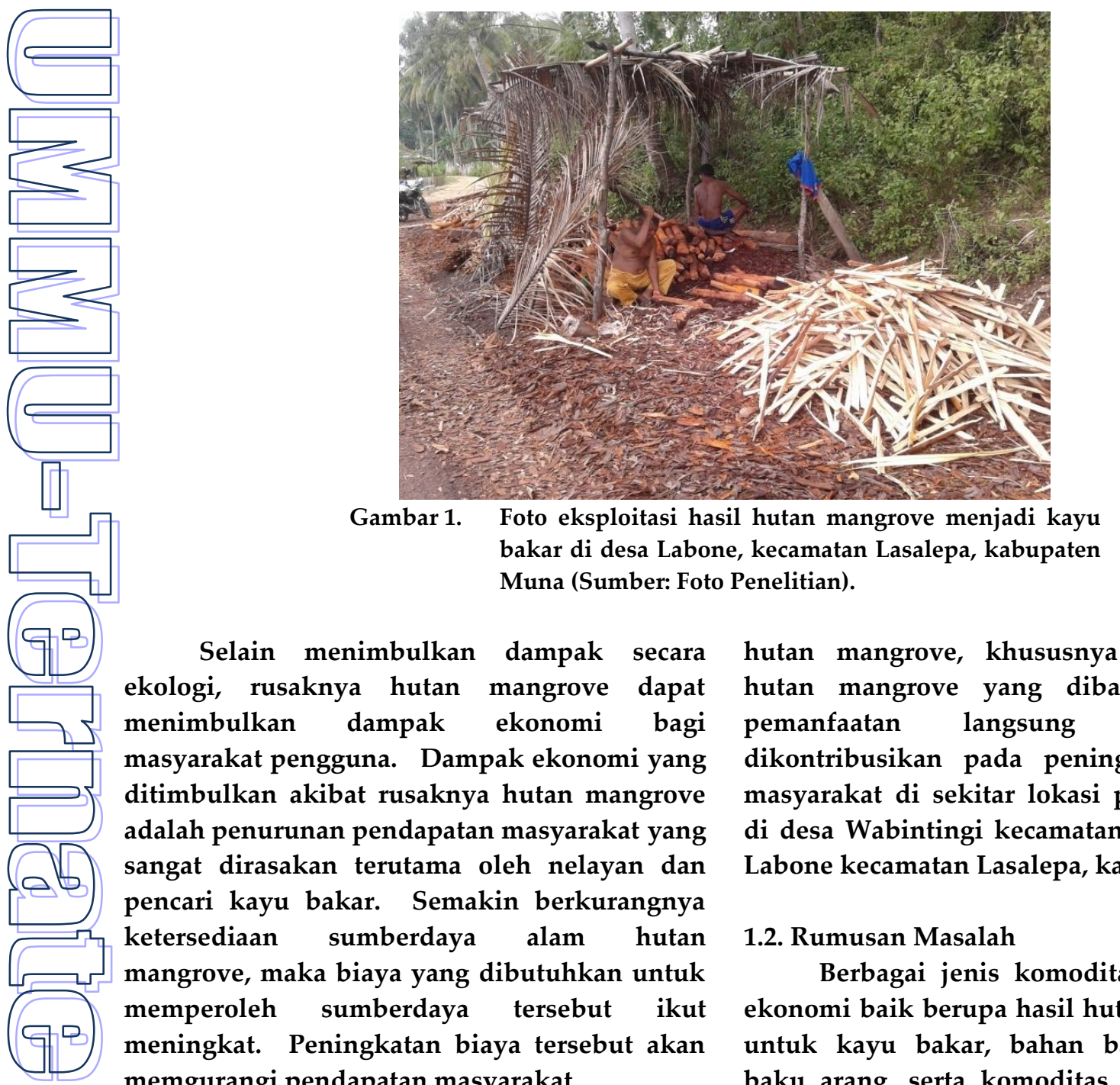

Selain menimbulkan dampak secara ekologi, rusaknya hutan mangrove dapat menimbulkan dampak ekonomi bagi masyarakat pengguna. Dampak ekonomi yang ditimbulkan akibat rusaknya hutan mangrove adalah penurunan pendapatan masyarakat yang sangat dirasakan terutama oleh nelayan dan pencari kayu bakar. Semakin berkurangnya ketersediaan sumberdaya alam hutan mangrove, maka biaya yang dibutuhkan untuk memperoleh sumberdaya tersebut ikut meningkat. Peningkatan biaya tersebut akan memgurangi pendapatan masyarakat.

Oleh karena itu, dipandang penting untuk melakukan kajian terhadap pemanfaatan hutan mangrove, khususnya nilai ekonomi hutan mangrove yang dibatasi pada nilai pemanfaatan langsung yang dapat dikontribusikan pada peningkatan ekonomi masyarakat di sekitar lokasi penelitian, yakni di desa Wabintingi kecamatan Lohia dan desa Labone kecamatan Lasalepa, kabupaten Muna.

\subsection{Rumusan Masalah}

Berbagai jenis komoditas yang bernilai ekonomi baik berupa hasil hutan, seperti; kayu untuk kayu bakar, bahan bangunan, bahan baku arang, serta komoditas hasil perikanan, seperti; ikan, udang, kepiting dan kerangkerangan. Potensi tersebut merupakan asset 


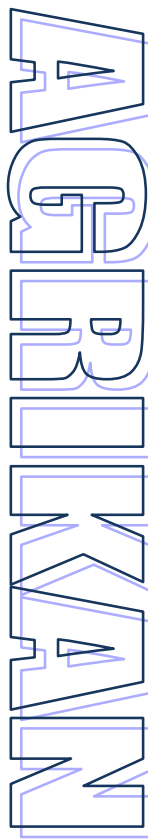

yang besar bagi pembangunan ekonomi masyarakat di daerah apabila dikelolah secara lestari. Selain itu, pemanfaatan dan pengelolaan hutan mangrove dalam menunjang ekonomi masyarakat pesisir menjadi perhatian khusus oleh karena peran dan fungsi hutan mangrove yang beranekaragam, seperti sebagai daerah pemijahan, pembesaran dan mencari makan berbagai jenis biota laut, serta fungsi perlindungan dan pengamanan pantai.

Dampak negatif yang akan timbul sebagai akibat dari kerusakan fisik atau bahkan hilangnya ekosistem hutan mangrove dapat berupa dampak ekologis, yakni berkurangnya luas daratan di wilayah pesisir sebagai akibat dari abrasi dan intrusi air laut. Kemudian dampak sosial dan ekonomi, yakni hilangnya mata pencaharian masyarakat yang menggantungkan kehidupan ekonominya dari kegiatan perikanan. Dampak dari kerusakan hutan mangrove dapat saja terus berlanjut apabila tidak ada solusi untuk mempertahankan keberadaan ekosistem hutan mangrove tersebut. Oleh karena itu maka dipandang perlu dilakukan kajian ekonomi secara lebih mendalam dan mendetail tentang manfaat dan fungsi hutan mangrove dari sisi ekonomi untuk dijadikan sebagai landasan dalam pengambilan kebijakan utamanya terkait pengelolaan sumberdaya hutan mangrove di Desa Labone dan Desa Wabinting, Kabupaten Muna.

1.3. Tujuan dan Manfaat Penelitian

Berdasarkan rumusan masalah tersebut, maka tujuan penelitian adalah untuk menganalisis :

1. Kondisi vegetasi hutan mangrove di Desa Wabintingi, Kecamatan Lohia dan Desa Labone, Kecamatan Lasalepa, Kabupaten Muna.

2. Jenis pemanfaatan hutan mangrove di Desa Wabintingi Kecamatan Lohia dan Desa Labone, Kecamatan Lasalepa, Kabupaten Muna.

3. Nilai ekonomi hutan mangrove pada berbagai kondisi vegetasi.

Penelitian diharapkan memberi manfaat sebagai berikut :

1. Sebagai bahan informasi ilmiah dalam pengambilan kebijakan pengelolaan dan pemanfaatan sumberdaya alam mangrove khususnya di desa Wabintingi kecamatan Lohia dan desa Labone kecamatan Lasalepa, kabupaten Muna.

2. Menambah wawasan ilmiah tentang konsep kondisi vegetasi mangrove dan nilai manfaat ekonomi sumberdaya alam khususnya mangrove.

3. Sebagai bahan referensi ilmiah bagi peneliti lainnya yang berminat untuk mengkaji bidang yang sama khususnya dalam perencanaan dan pengelolaam sumberdaya mangrove di Kabupaten Muna.

\section{METODE PENELITIAN}

\subsection{Tempat dan Waktu}

Penelitian dilaksanakan di desa Labone, Kecamatan Lasalepa dan di Desa Wabintingi, Kecamatan Lohia, Kabupaten Muna (Gambar 2), selama 6 bulan yakni bulan April September 2013.

\subsection{Alat dan Bahan}

Alat yang digunakan dalam pengukuran dan pengamatan vegetasi hutan terdiri atas roll meter (100 m), GPS (Global Positioning System), tali rafiah, patok skala, kamera digital, alat tulis menulis, dan buku panduang identifikasi mangrove. Untuk wawancara dan respondensi digunakan kuisioner.

\subsection{Populasi dan Sampel}

Populasi terdiri atas vegetasi hutan mangrove serta masyarakat yang memanfaatkan komoditas hutan mangrove secara langsung, yakni pengolah kayu bakar serta nelayan penangkap ikan, kepiting serta pengumpul kerang. Sampling vegetasi hutan mangrove dilakukan 3 (tiga) kali setiap lokasi penelitian mewakili kondisi hutan mangrove.

Masyarakat pengguna yang dijadikan responden adalah mereka yang memanfaatkan komoditas hutan mangrove berdasarkan jenis aktivitas pemanfaatan yang dilakukan. Sampling masyarakat pengguna terdiri atas pencari kayu bakar, penangkap ikan, penangkap kepiting, pengumpul kerang, penambang pasir, pedagang pengumpul hasil laut, pemerintah desa, tokoh masyarakat serta instansi terkait. 

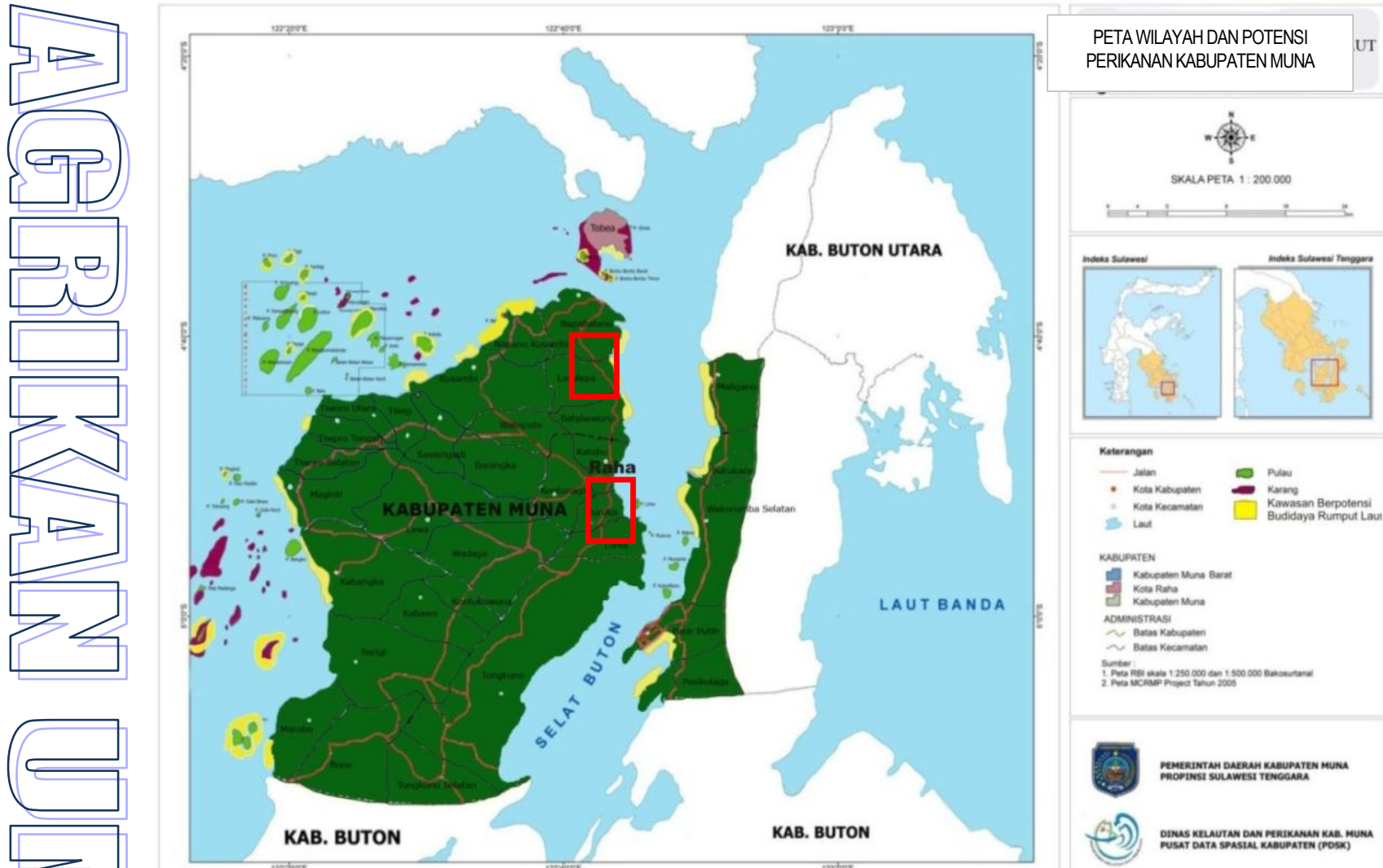

Gambar 2. Lokasi penelitian di Desa Labone Kecamatan Lasalepa dan Desa Wabintingi Kecamatan Lohia, Kabupaten Muna (Sumber: DKP Kab. Muna, 2010).

Proses seleksi pengumpulan data sampel masyarakat pengguna dilakukan dengan menggunakan teknik purposive sampling. Hal ini didasarkan pada pertimbangan bahwa sampel merupakan responden yang bersifat spesifik, sehingga penentuannya harus dilakukan secara sengaja (purposive).

\subsection{Prosedur Penelitian}

\subsubsection{Vegetasi Hutan Mangrove}

Metode pengukuran dan pengambilan data vegetasi menggunakan metode transek garis (line transek plot). Stasiun pengamatan dibuat setelah ditarik garis tegak lurus ke arah pantai. Sepanjang garis tersebut diletakkan secara acak petak (plot) pengamatan vegetasi hutan yang berukuran 10x10m. Kemudian dilakukan pengamatan dan pengukuran vegetasi mangrove. Jumlah garis transek yang dibuat sebanyak 3 (tiga) yang mewakili zona muara sungai bagian depan, tengah dan belakang. Hal ini dilakukan karena pertimbangan kondisi hutan mangrove yang relatif tebal dan disesuaikan dengan pertimbangan-pertimbangan lapangan.

\subsubsection{Nilai Ekonomi Hutan Mangrove}

Responden dipilih secara sengaja (purposive sampling) dari masyarakat di sekitar hutan mangrove serta yang memiliki akses terhadap hutan mangrove. Responden yang dipilih sebanyak 150 orang terdiri atas 71 orang di Desa Labone dan 50 orang di Desa Wabintingi serta 29 orang penduduk sekitar yang mengambil manfaat dari hutan mangrove. Wawancara dilakukan dengan masing-masing responden untuk memperoleh perkiraan nilai ekonomi yaitu: manfaat langsung, manfaat tidak langsung, manfaat pilihan, dan manfaat keberadaan dari hutan mangrove di Lohia dan Lasalepa.

\subsection{Variabel Penelitian}

Variabel yang akan diukur untuk pengukuran vegetasi hutan mangrove meliputi kerapatan dan kerapatan relatif, frekuensi dan frekuensi relatif, dominansi dan dominansi relatif (cover/jumlah individu) dan indeks nilai penting (INP). Sementara untuk pengukuran nilai ekonomi atau variabel nilai ekonomi penggunaan local (local use value) meliputi 


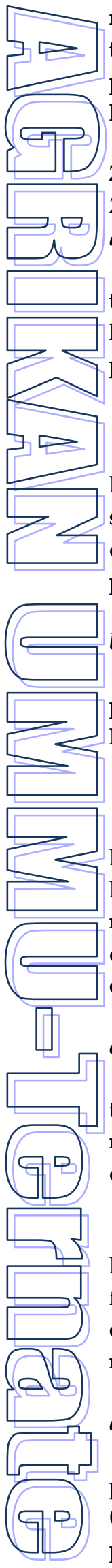

manfaat langsung (Direct Use Value), manfaat tidak langsung (Indirect Use Value), manfaat pilihan (Option Value), dan manfaat keberadaan (Existence Value).

\subsection{Analisis Data}

2.6.1. Analisis Vegetasi Mangrove

a. Kerapatan Spesies

Kerapatan spesies (Di) adalah jumlah tegakan jenis $i$ dalam suatu area. Nilai kerapatan spesies dihuting menggunakan persamaan (Bengen, 2002) berikut:

$$
\mathrm{Di}=\text { ni/A }
$$

Dimana diketahui Di merupakan Kerapatan spesies i, ni merupakan Jumlah total tegakan dari spesies i, dan A merupakan Luas total area pengambilan contoh.

\section{b. Penutupan Spesies}

Penutupan spesies (Ci) adalah luas penutupan spesies $i$ dalam suatu area. Persamaan dari penutupan spesies adalah:

$$
\mathrm{Ci}=\Sigma \mathrm{BA} \times \mathbf{A}
$$

Dimana diketahui BA merupakan nilai dari $\pi$ $\mathrm{DBH}^{2} / \mathrm{A}, \pi$ merupakan konstanta, DBH merupakan diameter batang pohon spesies $i$, dan A merupakan luas total area pengambilan contoh.

\section{c. Frekuensi Spesies}

Nilai yang terakhir yaitu nilai frekuensi tiap spesies. Frekuensi spesies sendiri merupakan peluang ditemukannya spesies $i$ dalam petak contoh plot yang diamati:

$$
\text { Fi }=\mathbf{P i} / \Sigma \mathbf{P}
$$

Dimana diketahui bahwa $F i$ merupakan frekuensi spesies i, Pi merupakan jumlah petak contoh/plot dimana ditemukan jenis $i$, dan $P$ merupakan jumlah total petak contoh/plot.

\section{d. Indeks Nilai Penting}

Indeks nilai penting (INP) adalah penjumlahan dari nilai kerapatan relatif spesies (RDi), frekuensi relatif spesies (RFi), dan penutupan relatif spesies (RCi).

$$
\mathrm{INP}=\mathrm{RDi}+\mathrm{RFi}+\mathrm{RCi}
$$

Nilai penting digunakan untuk memberikan suatu gambaran mengenai pengaruh atau peranan suatu jenis mangrove dalam ekosistem tersebut. Indeks nilai penting memiliki kisaran antara 0-300.

\subsubsection{Identifikasi Jenis Manfaat dan Fungsi Hutan Mangrove}

Nilai manfaat langsung yang diperoleh masyarakat disekitar hutan mangrove (local direct use value) didekati dengan laba bersih yang dihasilkan untuk penggunaan lokal (Sathirathai. 2003). Manfaat tidak langsung didekati dengan metode Replacement Cost (Metode Biaya Pengganti). Pendekatan tersebut digunakan untuk mengestimasi nilai manfaat fisik sumberdaya hutan mangrove, manfaat biologis dan manfaat ekologis dengan kriteria dan standar penilaian sebagaimana yang diajukan oleh Suryono (2006) dan Apung (2011). Untuk estimasi nilai manfaat pilihan menggunakan pendekatan benefit transfer dengan kriteria sebagaimana yang diajukan oleh Ruitenbeek (1992). Sementara itu estimasi nilai manfaat keberadaan dengan menggunakan metode Contingent Valuation.

2.6.1.1. Jenis Manfaat Langsung

a) Manfaat langsung pembuatan atap adalah nilai ekonomi yang diperoleh dari pengambilan daun nipa yang dijadikan bahan pembuatan atap bangunan, yang dihitung berdasarkan jumlah lembar atap bangunan yang dihasilkan. Perhitungan jumlah total nilai manfaat didekati dengan persamaan sebagai berikut :

$\mathrm{NEAb}=\mathrm{QAb} \times \mathrm{PAb} \times \mathrm{RTAb}-\mathrm{CAb}$

Dimana diketahui NEAb merupakan nilai ekonomi atap bangunan (Rp/tahun), QAb merupakan jumlah nilai atap bangunan (lembar/tahun), PKb merupakan harga atap bangunan (Rp/lembar), RTAb merupakan jumlah rumah tangga pengrajin atap bangunan (kk), CAb merupakan biaya

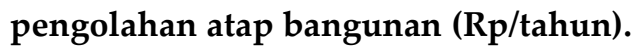

b) Manfaat langsung kayu bakar adalah nilai ekonomi yang diperoleh dari pengolahan kayu mangrove menjadi kayu bakar, didekati dengan persamaan berikut :

$\mathrm{NEKb}=\mathrm{QKb} \times \mathrm{PKb} \times \mathrm{RTKb}-\mathrm{CKb}$ 


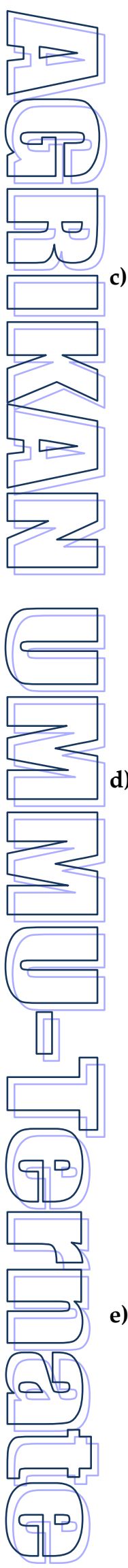

Dimana diketahui NEKb merupakan nilai ekonomi kayu bakar (Rp/tahun), QKb merupakan nilai jumlah volume kayu bakar ( $\mathrm{m}^{3} /$ tahun), PKb merupakan harga kayu bakar $\left(\mathrm{Rp} / \mathrm{m}^{3}\right)$, RTKb merupakan jumlah rumah tangga pengolah kayu bakar (kk), CKb merupakan biaya pengolahan kayu bakar (Rp/tahun).

c) Manfaat langsung penangkapan ikan/udang adalah nilai ekonomi yang diperoleh dari penangkapan ikan/udang, didekati dengan persamaan berikut :

NEPi = QPi $\times$ PPi $\times$ RTPi - CPi

Dimana diketahui NEPi merupakan nilai ekonomi penangkapan ikan/udang (Rp/tahun), QPi merupakan jumlah ikan/udang hasil tangkapan (kg), PPi merupakan harga jual ikan/udang hasil tangkapan (Rp/kg), RTPi merupakan jumlah nelayan penangkap ikan/udang (orang), dan $\mathrm{CPi}$ merupakan biaya penangkapan ikan/udang (Rp/tahun).

d) Manfaat langsung penangkapan kepiting adalah nilai ekonomi yang diperoleh dari penangkapan kepiting, didekati dengan persamaan berikut :

NEPk $=$ QPk $\times$ PPk $\times$ RTPk - CPk

Dimana diketahui NEPk merupakan nilai ekonomi penangkapan kepiting (Rp/tahun), QPk merupakan jumlah kepiting hasil tangkapan (kg), PPk merupakan harga jual ikan hasil tangkapan (Rp/kg), RTPk merupakan Jumlah nelayan penangkap kepiting (orang), dan CPk merupakan biaya operasional penangkapan kepiting (Rp/tahun).

e) Manfaat langsung pengumpulan kerang adalah nilai ekonomi yang diperoleh dari penangkapan kerang, didekati dengan persamaan berikut :

\section{NEPkr $=$ QPkr x PPkr x RTPkr - CPkr}

Dimana diketahui NEPkr merupakan nilai ekonomi pengumpulan kerang (Rp/tahun), QPkr merupakan jumlah kerang hasil pengumpulan (kg), PPkr merupakan harga jual kerang hasil pengumpulan (Rp/kg), RTPkr merupakan jumlah nelayan pengumpul kerang (orang), dan CPkr merupakan biaya operasional pengumpulan kerang (Rp/tahun).

\subsubsection{Nilai Ekonomi Hutan Mangrove}

a. Manfaat Langsung

Manfaat langsung atau Dierct Use Value adalah merupakan jenis manfaat yang lansung dapat diperoleh dari hutan mangrove atau sebagai bentuk manfaat aktual yang dilakukan oleh masyarakat, seperti mengolah kayu bakar, menangkap ikan, menangkap kepiting, menangkap udang, mengumpulkan kerang dan lain-lain, dihitung menggunakan persamaan Fauzi (2006) sebagai berikut :

$$
\mathrm{TML}=\mathrm{ML}_{1}+\mathrm{ML}_{2}+\mathrm{ML}_{3}+\mathrm{ML}_{4}+\mathbf{n}
$$

Dimana diketahui bahwa TML merupakan Total Nilai Manfaat Langsung, TML1 merupakan Nilai Manfaat Langsung Kayu Bakar, ML2 merupakan nilai Manfaat Langsung Penangkapan Ikan, ML 3 merupakan nilai Manfaat Langsung Penangkapan Kepiting, dan ML4 merupakan nilai Manfaat Langsung Pengumpulan Kerang. Sementara $\mathbf{n}$ merupakan jenis manfaat langsung lainnya.

b. Manfaat Tidak Langsung

Perhitungan manfaat tidak langsung hutan mangrove digunakan metode replacement cost. Manfaat tidak langsung dari hutan mangrove diperoleh dari suatu ekosistem secara tidak langsung, yakni berupa manfaat fisik, biologis dan ekologis (Suryono, 2006). Manfaat tidak langsung fisik yakni sebagai penahan abrasi pantai (Fahrudin, 1996) dinilai dari adanya pembuatan bangunan air yaitu pemecah gelombang ombak (break water) (Suryono, 2006); manfaat tidak langsung biologis yakni sebagai penyedia bahan-bahan organik bagi biota yang hidup di dalam kawasan hutan mangrove (Melanni, 1996; Adrianto, 2004) maupun sebagai tempat pemijahan dan asuhan (Suryono, 2006) dan manfaat tidak langsung ekologis yakni diestimasi dari adanya serapan karbon.

Formula yang digunakan untuk menghitung nilai manfaat tidak langsung yang dihitung sesuai dengan nilai rupiah adalah : 

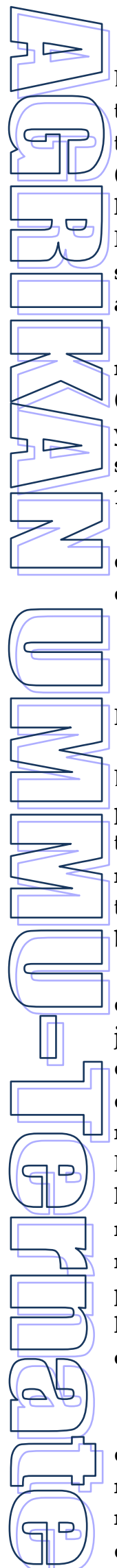

Dimana diketahui MTL merupakan Manfaat tidak langsung, MTL1 merupakan Manfaat tidak langsung sebagai peredam gelombang (break water), MTL2 merupakan Manfaat tidak langsung sebagai penyedia bahan organik, dan MTL3 merupakan Manfaat tidak langsung sebagai penyerap karbon.

a. Manfaat Pilihan

Nilai manfaat pilihan didekati dengan mengacu pada nilai keanekaragaman hayati (biodiversity) hutan mangrove di Indonesia, yakni sebesar USD 1.500 per $\mathrm{km}^{2}$ per tahun atau sebesar USD 15 per ha per tahun (Ruitenbeek, 1992).

Untuk mengetahui nilai manfaat pilihan dari hutan mangrove, digunakan pendekatan dengan formula sebagai berikut :

$\mathrm{MP}=\mathrm{MPb}$

$=($ USD 15 per ha) $x$ Luas Hutan

Mangrove

Dimana diketahui MP merupakan manfaat pilihan. Perhitungan nilai manfaat pilihan tersebut dilakukan dengan mengkonversikan nilai keanekaragaman hayati USD 15 per ha tersebut ke dalam nilai rupiah.

b. Manfaat Keberadaan

Manfaat keberadaan atau lebih dikenal dengan istilah manfaat eksistensi merupakan jenis manfaat yang dirasakan oleh masyarakat dari keberadaan ekosistem hutan mangrove dari manfaat lainnya, yakni manfaat langsung, manfaat tidak langsung, dan manfaat pilihan. Manfaat keberadaan merupakan nilai ekonomi keberadaan secara fisik dari ekosistem hutan mangrove. Metode yang digunakan untuk menghitung besarnya nilai ekonomi melalui pendekatan Contingent Valuation Method atau lebih dikenal dengan CVM.

c. Kuantifikasi Seluruh Manfaat dan Fungsi Hutan Mangrove

Setelah seluruh komoditas dari mangrove dapat diidentifikasi, selanjutnya adalah mengkuantifikasi seluruh komoditas ke dalam nilai rupiah. Teknik kuantifikasi yang digunakan adalah:

1) Nilai pasar lokal

2) Harga tidak langsung.
3) Contingent Valuation Method (CVM).

4) Nilai Ekonomi Total (NET)/Total Economic Value (TEV), merupakan penjumlahan dari nilai pemanfaatan dan nilai bukan pemanfaatan hutan mangrove yang telah diidentifikasi dan dikuantifikasikan. Untuk mengetahui nilai ekonomi total (NET/TEV) adalah sebagai berikut :

$\mathrm{NET}=\mathrm{ML}+\mathrm{MTL}+\mathrm{MP}+\mathrm{ME}$

Dimana diketahui NET merupakan nilai ekonomi total, ML merupakan manfaat langsung, MTL merupakan nilai manfaat tidak langsung, MP merupakan nilai manfaat pilihan, dan ME merupakan nilai manfaat eksistensi.

\section{HASIL DAN PEMBAHASAN}

\subsection{Vegetasi Hutan Mangrove}

\subsubsection{Hutan Mangrove Desa Labone}

Kondisi vegetasi hutan mangrove meliputi kerapatan relatif jenis (RDi), penutupan jenis $(\mathrm{Ci})$, penutupan relatif jenis (RCi) dan indeks nilai penting jenis (INPi) pada sublokasi 1 (jauh dari sungai) sebagaimana pada Tabel 1, sublokasi 2 (dekat sungai) pada Tabel 2, dan sublokasi 3 (jauh dari sungai) pada Tabel 3.

Spesies dominan yang berperan penting dalam menjaga kestabilan ekosistem di sublokasi tersebut adalah jenis Ceriops tagal (INP 136,394), Rhizophora apiculata (INP 67,441). Dominasi spesies Ceriops tagal dibanding dengan spesies lain tidak terlepas dari kondisi pesisir pada sublokasi pengamatan yang relatif berbatu, dimana spesies tersebut mampu beradaptasi secara morfologi maupun anatomi dengan baik pada substrat berbatu. Sementara itu spesies Rhizophora apiculata merupakan jenis mangrove dengan tingkat adaptasi yang relatif cukup tinggi pada kondisi substrat tertentu. Indikator vegetasi hutan mangrove yakni kerapatan relatif jenis (RDi), penutupan jenis $(\mathrm{Ci})$, penutupan relatif jenis (RCi) dan indeks nilai penting jenis (INPi), hutan mangrove di sublokasi jauh dari sungai tersebut mengalami kerusakan (Gambar 2). 


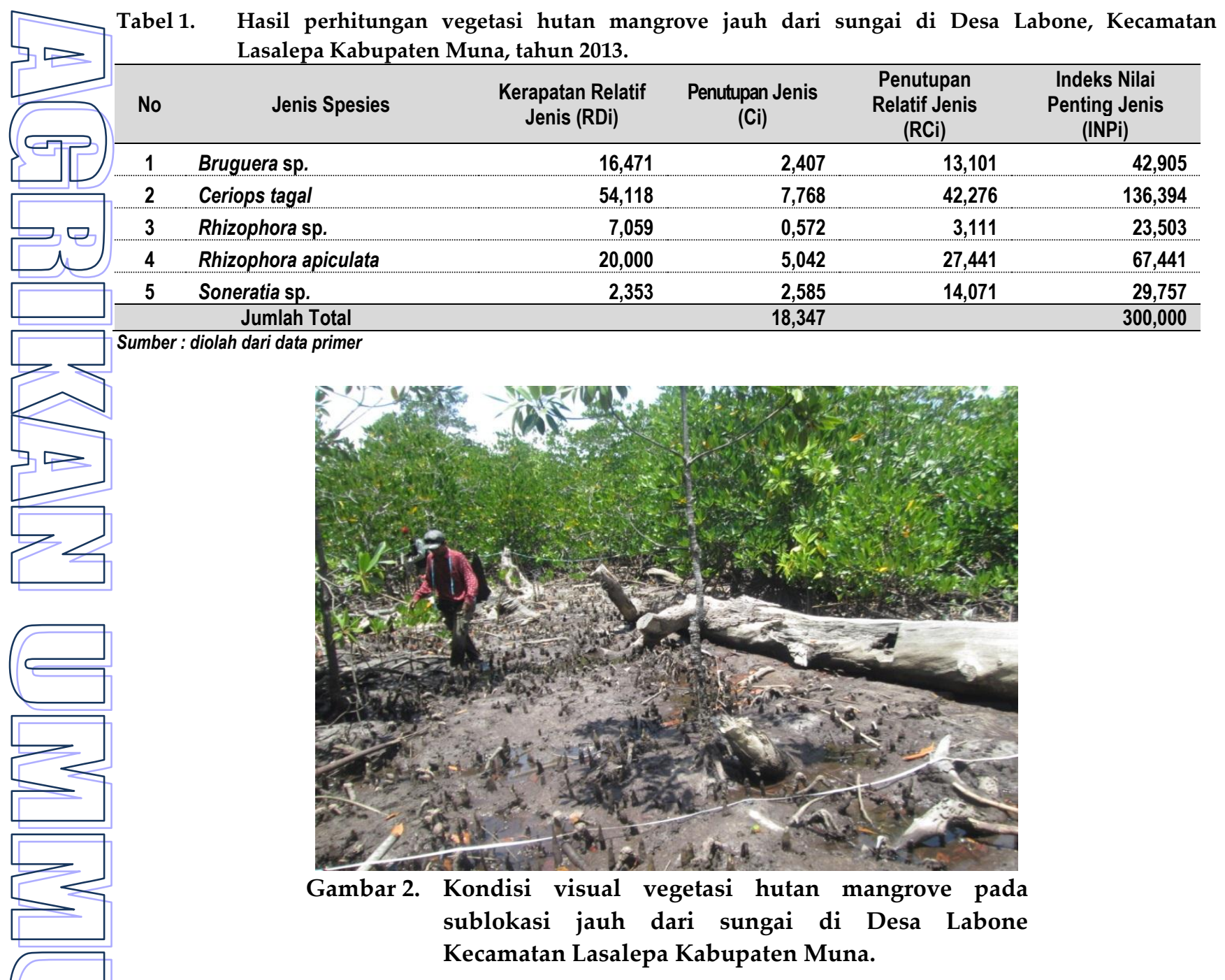

Di daerah dekat sungai vegetasi hutan mangrove INPi jenis Rhizophora apiculata (109,607), Rhizophora sp. $(93,597)$, Bruguera marina $(45,071)$, Soneratia sp. $(31,500)$ dan Bruguera sp. $(20,224)$. Indeks nilai penting jenis (INPi) tersebut menunjukkan dominasi suatu spesies menjaga kestabilan ekosistem hutan mangrove, di dominasi oleh jenis Rhizophora apiculata, nilai penutupan jenis (Ci) 27,932 (Tabel 2).

Tingkat penutupan tertinggi Rhizophora apiculata 18,482 (RCi 66,170\%) dari total luas pengamatan. Penutupan jenis Rhizophora sp. 7,580 , penutupan relatif $27,139 \%$, kerapatan relatif jenis $53,125 \%$. Penutupan jenis Bruguera sp. 0,179 , penutupan relatif jenis $0,641 \%$, kerapatan relatif jenis $6,250 \%$. Penutupan jenis Soneratia sp. 1,583, penutupan relatif jenis $5,667 \%$, kerapatan relatif jenis $12,500 \%$. Penutupan jenis Bruguera marina 0,107, penutupan relatif jenis dan kerapatan relatif jenis masing-masing $0,383 \%$ dan $4,688 \%$. Berdasarkan hal tersebut yang dibandingkan dengan kriteria baku kerusakan hutan mangrove, kondisi vegetasi hutan mangrove pada daerah dekat sungai tergolong rusak dengan kategori tingkat kerapatan jarang (Gambar 3).

Berdasarkan Tabel 3, vegetasi hutan mangrove dengan indikator kerapatan relatif jenis (RDi), penutupan jenis (Ci), penutupan relatif jenis (RCi) serta indeks nilai penting jenis (INPi) secara berturut-turut adalah Rhizophora sp. $75,000 \%$, 2,942, 78,117\% dan 178,117 , jenis Soneratia alba 12,500\%, 0,482, $12,788 \%$ dan 50,288 , jenis Soneratia sp. $6,250 \%$, 0,306, 8,118\% dan 39,368 dan jenis Bruguera sp. $6,250 \%, 0,037,0,977 \%$ dan 32,227. Total penutupan jenis mencapai $3,766<50$, dengan nilai INP tertinggi adalah jenis Rhizophora sp., menunjukkan kondisi hutan mangrove berada pada kondisi rusak dengan kategori jarang. 


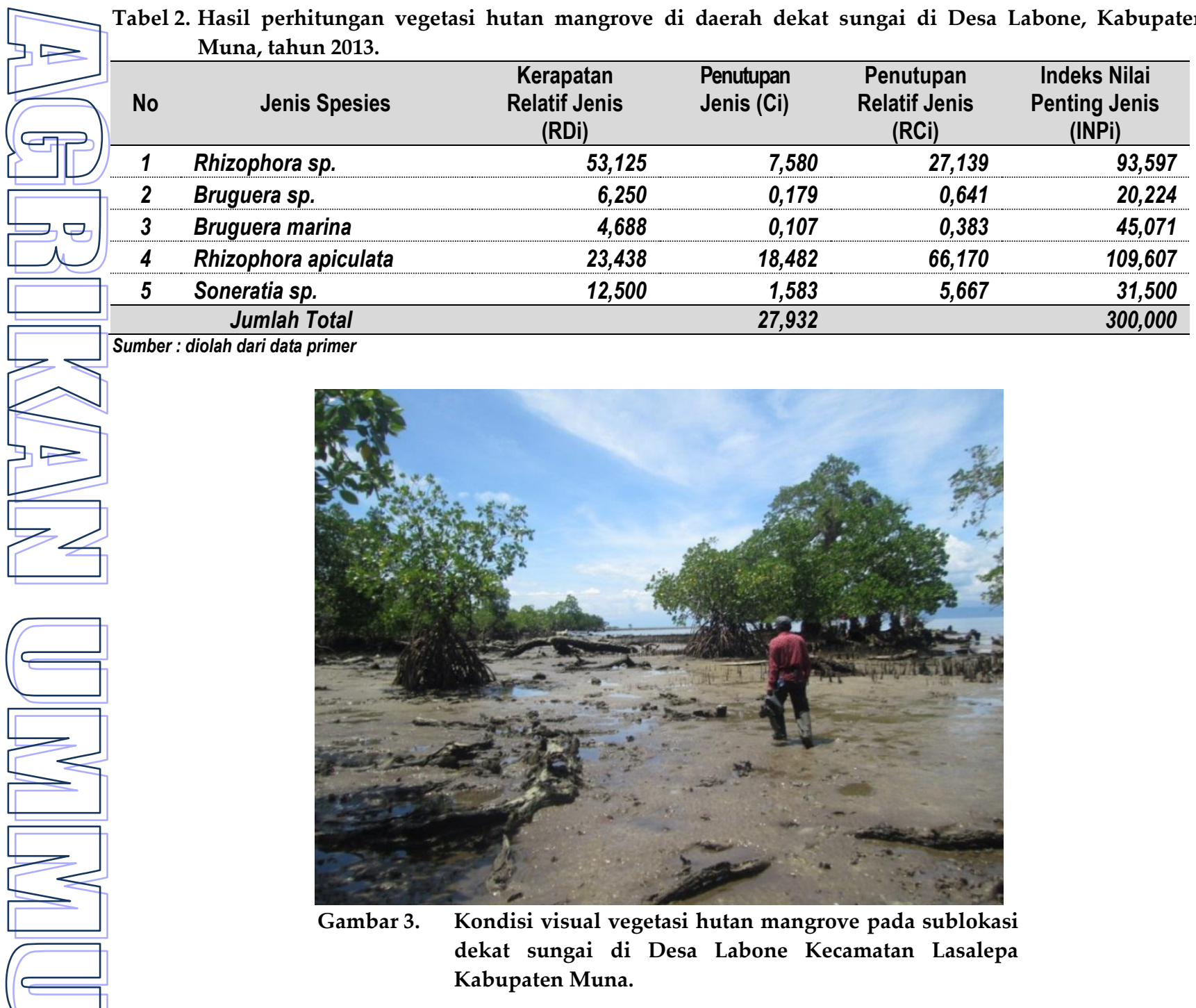

Tabel 3. Hasil perhitungan vegetasi hutan mangrove di daerah jauh dari sungai di Desa Labone, Kabupaten Muna, tahun 2013.

\begin{tabular}{|c|c|c|c|c|c|}
\hline No & Jenis Spesies & $\begin{array}{c}\text { Kerapatan } \\
\text { Relatif Jenis } \\
\text { (RDi) }\end{array}$ & $\begin{array}{l}\text { Penutupan } \\
\text { Jenis (Ci) }\end{array}$ & $\begin{array}{l}\text { Penutupan } \\
\text { Relatif Jenis } \\
\text { (RCi) }\end{array}$ & $\begin{array}{l}\text { Indeks Nilai } \\
\text { Penting Jenis } \\
\text { (INPi) }\end{array}$ \\
\hline 1 & Rhizophora sp. & 75,000 & 2,942 & 78,117 & 178,117 \\
\hline 2 & Soneratia alba & 12,500 & 0,482 & 12,788 & 50,288 \\
\hline 3 & Soneratia sp. & 6,250 & 0,306 & 8,118 & 39,368 \\
\hline 4 & Bruguera sp. & 6,250 & 0,037 & 0,977 & 32,227 \\
\hline & Jumlah Total & & 3,766 & & 300,000 \\
\hline
\end{tabular}

Sumber : diolah dari data primer

Berdasarkan tinjauan terhadap ketiga sublokasi tersebut dengan indikator nilai penutupan jenis $(<50)$, hutan mangrove Desa Labone telah mengalami kerusakan. Kerusakan tersebut ditemukan pada hampir semua sublokasi pengamatan. Terjadinya kerusakan ditengarai karena adanya aktifitas ekstraktif masyarakat berupa pengambilan kayu secara tidak terkendali. Menurut infomasinya yang kami peroleh dari masyarakat setempat, aktifitas tersebut telah berlangsung lama dengan jumlah pengambil manfaat yang terus bertambah. Hal ini menggambarkan tingginya tekanan terhadap vegetasi hutan mangrove. Peningkatan aktifitas pengambilan hasil hutan mangrove 


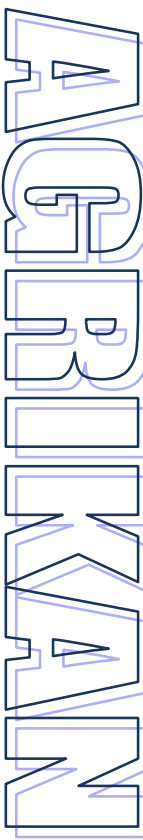

tersebut bahkan telah masuk ke daerah luar wilayah Desa Labone yang memiliki hutan mangrove. Aktifitas pengambilan hasil hutan tersebut jelas mengakibatkan penurunan kerapatan dan penutupan jenis hutan mangrove.

\subsubsection{Hutan Mangrove Desa Wabintingi}

Hasil perhitungan indikator vegetasi hutan mangrove meliputi kerapatan relatif jenis (RDi), penutupan jenis (Ci), penutupan relatif jenis (RCi) dan indeks nilai penting jenis (INPi) pada sebelah kiri sungai Tabel 4, dekat sungai Tabel 5, dan sebelah kanan sungai Tabel 6.

Vegetasi hutan mangrove terdiri atas Soneratia alba, Bruguera vilosa, Rhizophora apiculata, Bruguera gymnorhiza, Soneratia sp., dan Avicenia marina. Nilai penutupan jenis (Ci) 104,909, nilai tersebut lebih besar dari kriteria baku, yakni vegetasi hutan mangrove kategori baik, tingkat penutupan padat.
Penutupan tertinggi jenis Soneratia alba $54,238 \%$, Bruguera vilosa 25,625\%, Bruguera gymnorhiza, Rhizophora apiculata, Avicenia marina dan Soneratia sp. $<25 \%$.

Vegetasi hutan mangrove di dekat muara sungai disajikan Tabel 5, dengan nilai INP tertinggi ke rendah secara berutur-turut Bruguera apiculata 129,411, Bruguera sp. 46,458, Rhizophora sp. 33,161, Soneratia alba 32,160, Avicenia marina 23,079, Soneratia sp. 18,536 dan Bruguera gymnorhiza 16,995.

Nilai penutupan jenis (Ci) dekat sungai tersebut mencapai 25,480, lebih rendah dari kriteria baku, kategori jarang (Ci 25,480<50). Penutupan jarang tidak bermakna adanya kerusakan hutan melainkan usia tanaman telah tua dan rimbun, sehingga penutupan relatif rendah (Rochmady, 2011).

Sementara itu hasil perhitungan indikator kondisi vegetasi hutan mangrove pada sublokasi 3 sebagaimana ditunjukkan pada Tabel 6.

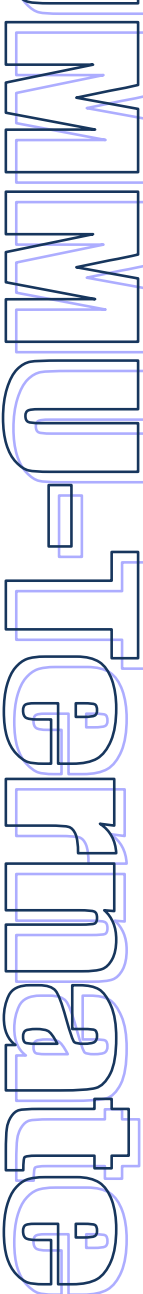

Tabel 4. Hasil perhitungan vegetasi hutan mangrove di daerah jauh dari sungai di Desa Wabintingi, Kabupaten Muna, tahun 2013.

\begin{tabular}{|llrrrr}
\hline No & Jenis Spesies & $\begin{array}{c}\text { Kerapatan } \\
\text { Relatif Jenis } \\
\text { (RDi) }\end{array}$ & $\begin{array}{c}\text { Penutupan } \\
\text { Jenis (Ci) }\end{array}$ & $\begin{array}{c}\text { Penutupan } \\
\text { Relatif Jenis } \\
\text { (RCi) }\end{array}$ & $\begin{array}{c}\text { Indeks Nilai } \\
\text { Penting Jenis } \\
\text { (INPi) }\end{array}$ \\
\hline 1 & Bruguera gymnorhiza & 2,198 & 7,457 & 7,108 & 20,933 \\
\hline 2 & Rhizopora apiculata & 14,286 & 12,236 & 11,663 & 32,926 \\
\hline 3 & Bruguera vilosa & 30,769 & 26,883 & 25,625 & 91,278 \\
\hline 4 & Avicenia marina & 1,099 & 0,003 & 0,002 & 18,543 \\
\hline 5 & Soneratia alba & 45,055 & 56,900 & 54,238 & 116,734 \\
\hline 6 & Soneratia sp. & 6,593 & 1,431 & 1,364 & 19,585 \\
\hline & Jumlah Total & & 104,909 & & 300,000 \\
\hline Sumber $:$ diolah dari data primer & & & & & \\
\hline
\end{tabular}

Tabel 5. Hasil perhitungan vegetasi hutan mangrove di daerah dekat sungai di Desa Wabintingi, Kabupaten Muna, tahun 2013.

\begin{tabular}{clrrrr}
\hline No & Jenis Spesies & $\begin{array}{c}\text { Kerapatan } \\
\text { Relatif Jenis } \\
\text { (RDi) }\end{array}$ & $\begin{array}{c}\text { Penutupn } \\
\text { Jenis (Ci) }\end{array}$ & $\begin{array}{c}\text { Penutupan } \\
\text { Relatif Jenis } \\
\text { (RCi) }\end{array}$ & $\begin{array}{c}\text { Indeks Nilai } \\
\text { Penting Jenis } \\
\text { (INPi) }\end{array}$ \\
\hline 1 & Bruguera gymnorhiza & 3,125 & 0,986 & 3,870 & 16,995 \\
\hline 2 & Rhizopora apiculata & 46,875 & 18,482 & 72,536 & 129,411 \\
\hline 3 & Bruguera sp. & 21,875 & 3,767 & 14,783 & 46,658 \\
\hline 4 & Avicenia marina & 6,250 & 0,466 & 1,829 & 23,079 \\
\hline 5 & Rhizopora sp. & 3,125 & 0,009 & 0,036 & 33,161 \\
\hline 6 & Soneratia alba & 12,500 & 1,187 & 4,660 & 32,160 \\
\hline 7 & Soneratia sp. & 6,250 & 0,583 & 2,286 & 18,536 \\
\hline & Jumlah Total & & 25,480 & & 300,000 \\
\hline
\end{tabular}

Sumber : diolah dari data primer 


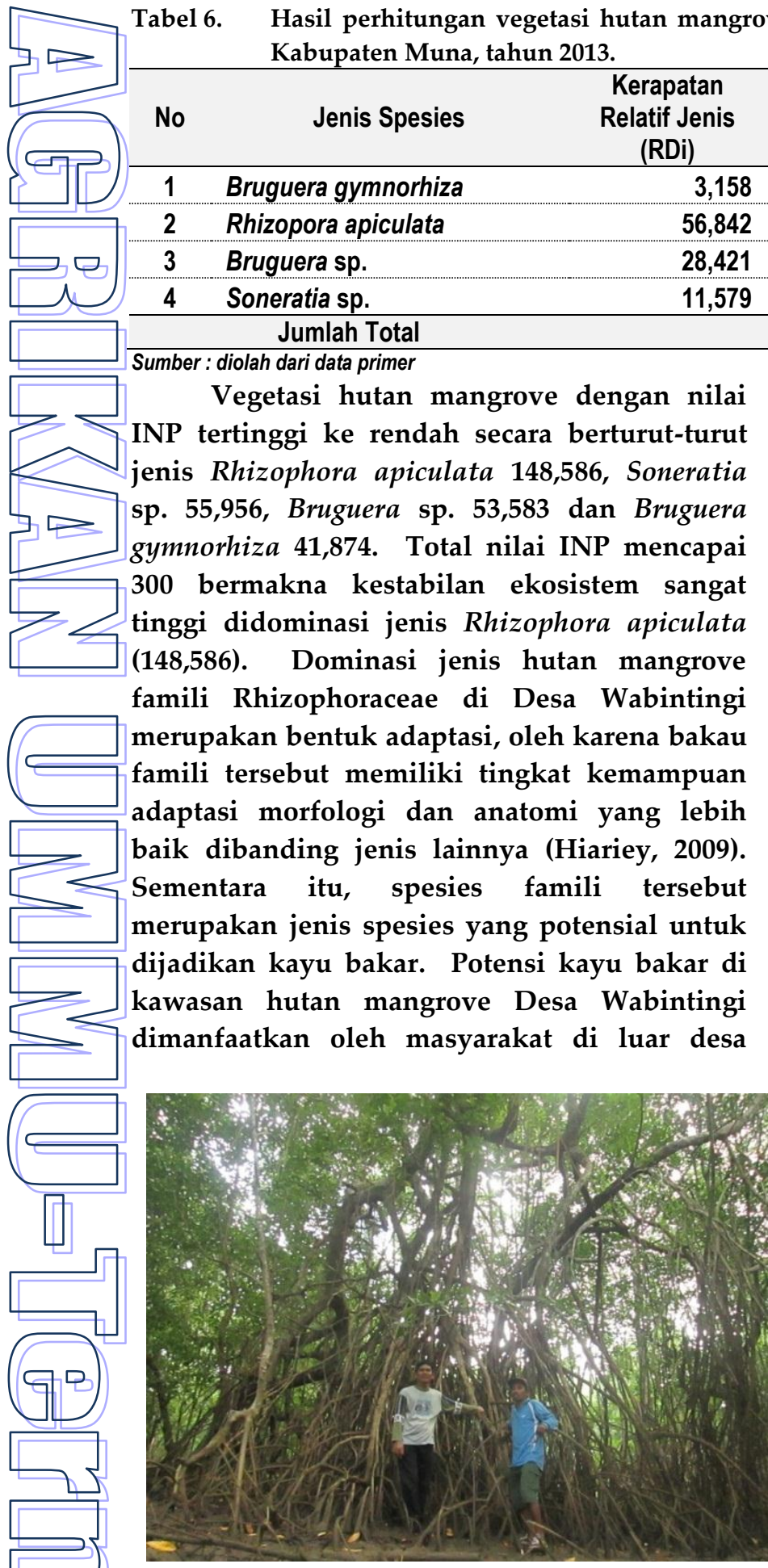

Gambar 4. Kondisi visual vegetasi hutan mangrove pada sublokasi jauh dari sungai di Desa Wabintingi Kecamatan Lohia

Pemanfaatan secara fisik lebih pada penggunaan keunikan pohon mangrove sebagai tambatan perahu bagi para nelayan sekitar hutan. Bentuk lainnya adalah pengambilan daun nipa yang dijadikan sebagai bahan pembuatan atap. Kegiatan tersebut namun belum melampaui ambang batas daya dukung sumberdaya.

Secara visual memperlihatkan kondisi hutan mangrove Desa Wabintingi di daerah yang jauh dari sungai (Gambar 4) dan vegetasi dekat sungai (Gambar 5) dengan kondisi relatif baik. Diduga aktifitas pemanfaatan secara fisik oleh masyarakat lokal relatif kecil, jikapun ada kegiatan tersebut tidak melampuai daya dukung sumberdaya sehingga kondisi sumberdaya relatif terjaga dengan baik. Jenis pemanfaatan secara fisik dimaksud adalah pengambilan kayu bakau secara terkendali maupun secara tidak terkendali. Aktifitas pemanfaatan lebih mengarah pada pemanfaatan fungsional yakni secara biologis maupun ekologis.

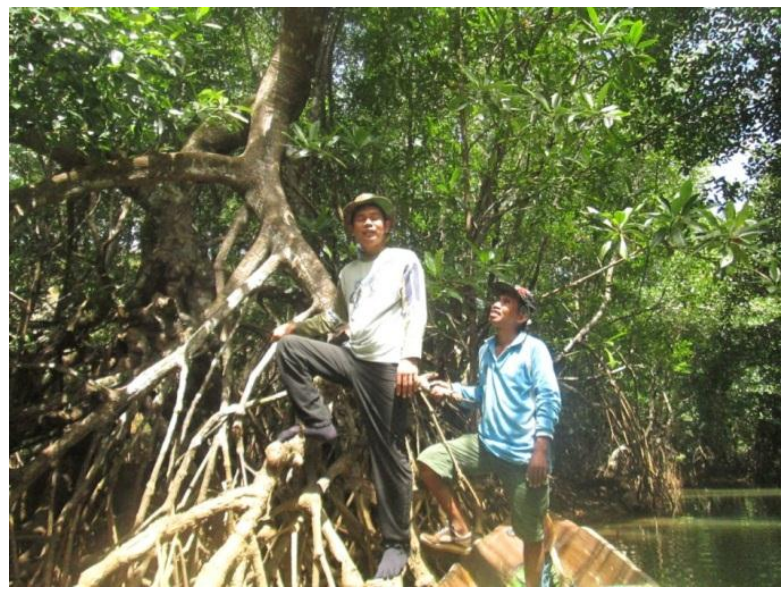

Gambar 5. Kondisi visual vegetasi hutan mangrove pada sublokasi dekat sungai di Desa Wabintingi Kecamatan Lohia.

relatif tidak merusak sumberdaya hutan mangrove, melainkan hanya memanfaatkan daun dari jenis tumbuhan yang merupakan formasi terakhir dari ekosistem mangrove. Sementara pemanfaatan secara biologis, lebih dominan dijadikan sebagai tempat untuk 


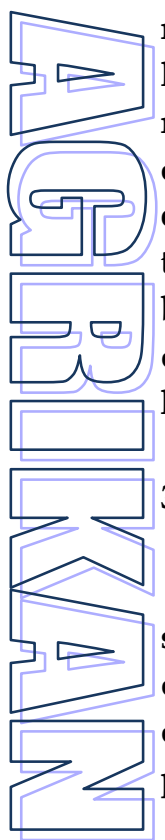

menangkap ikan, udang, kepiting, maupun kerang-kerangan, mengingat hutan mangrove merupakan tempat dengan kandungan nutrien cukup tinggi sehingga memungkinkan organisme laut seperti ikan, udang-udangan termasuk kepiting dan kerang-kerangan relatif berlimpah sehingga mampu memberi daya dukung bagi kehidupan organisme laut sekitar hutan mangrove.

3.2. Identifikasi Jenis Manfaat dan Fungsi Hutan Mangrove

Hutan mangrove dan masyarakat sekitarnya memiliki hubungan yang sangat erat dan merupakan satu kesatuan yang tidak dapat dipisahkan. Kondisi demikian terjadi pula pada masyarakat di wilayah pesisir Desa

Labone Kecamatan Lasalepa dan Desa Wabintingi Kecamatan Lohia, Kabupaten Muna yang mendiami daerah sekitar hutan mangrove. Hal ini diketahui melalui jenis kegiatan ekonomi masyarakat dalam pemanfaatan hutan mangrove oleh masyarakat yang relatif cukup beragam. Masyarakat boleh saja memanfaatkan hutan mangrove, namun aspek kelestarian dan keberlanjutan (sustainable) baik secara ekologi, ekonomi maupun sosial harus tetap diperhatikan.

\subsubsection{Jenis Pemanfaatan di Desa Labone}

Hasil responden di Desa Labone Kecamatan Lasalepa, teridentifikasi jenis manfaat hutan mangrove dengan nilai rata-rata pemanfaatan masing-masing jenis pemanfaatan sebagaimana terlihat pada Tabel 7.

Tabel 7. Jenis Kegiatan Pemanfaatan Langsung Sumberdaya Hutan Mangrove di Desa Labone,

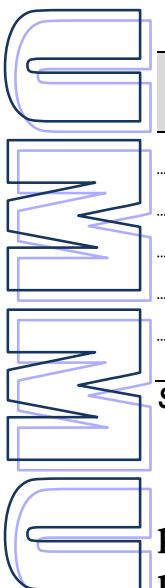
Kecamatan Lasalepa, Kabupaten Muna.

\begin{tabular}{|c|c|c|}
\hline No & Jenis Kegiatan Pemanfaatan & Rata-rata Pemanfaatan Pertahun \\
\hline 1 & Pasir & $900 \mathrm{~m}^{3}$ \\
\hline 2 & Atap bangunan & 600 lembar \\
\hline 3 & Kayu bakar & $1.078 \mathrm{~m}^{3}$ \\
\hline 4 & Kepiting & $57 \mathrm{~kg}$ \\
\hline 5 & Ikan & $775 \mathrm{~kg}$ \\
\hline 6 & Kerang-kerangan & $1.800 \mathrm{~kg}$ \\
\hline
\end{tabular}

Sumber : data primer penelitian.

Berdasarkan Tabel 7, diketahui jenis pemanfaatan hutan mangrove terdiri atas penambangan pasir, kerajinan atap daun nipa, pengambilan kayu bakar, penangkapan kepiting, ikan dan pengumpulan kerangkerangan. Kegiatan pemanfaatan dilakukan ditengah kondisi hutan mangrove yang relatif rusak serta dengan kerapatan vegetasi relatif rendah. Vegetasi tersisa dominan jenis Ceriops tagal, Rhizophora apiculata, Rhizophora sp. dan beberapa jenis dari famili Sonneratiaceae (Tabel 1, 2, dan 3).

Responden yang memanfaatkan kawasan hutan mangrove sebagai tempat menambang pasir merupakan peralihan dari masyarakat yang sebelumnya berprofesi sebagai pengambil kayu bakar. Namun karena kayu yang dimanfaatkan telah menurun, maka sebagian besar pengambil kayu tersebut beralih profesi menjadi penambang pasir, dengan rata-rata hasil penambangan pasir mencapai $900 \mathrm{~m}^{3}$ per tahun.
Nipa sebagai formasi terakhir dari hutan mangrove dimanfaatkan oleh masyarakat sekitar hutan sebagai bahan pembuatan atap bangunan. Daun nipa diolah dengan menggunakan parang serta peralatan sederhana lainnya berupa kayu dan bambu. Rata-rata hasil pembuatan atap bangunan mencapai 600 lembar per tahun. Sementara para responden pengambil kayu mangrove jenis Rhizophora apiculata famili Rhizphoraceae ukuran lingkaran batang rata-rata kisaran $15-40 \mathrm{~cm}$. Hasil kayu bakar dijual kepada pedagang pengumpul hingga ke pasar-pasar dengan hasil pemanfaatan mencapai $1.078 \mathrm{~m}^{3}$ per tahun.

Manfaat kepiting yakni kepiting rajungan dan kepiting bakau. Jumlah pemanfaatan rata-rata mencapai $57 \mathrm{~kg}$ per tahun. Manfaat ikan dari penangkapan di sekitar kawasan hutan mangrove. Jenis ikan yang ditangkap oleh nelayan disekitar hutan mangrove seperti ikan belanak dan beberapa jenis lainnya dengan rata-rata pemanfaatan mencapai $775 \mathrm{~kg}$ per tahun. Manfaat kerang- 
kerangan adalah jenis ghiwo (kerang lumpur), bulou (anadara) dan berbagai jenis kerang, dengan frekuensi pemasaran setiap 3 (tiga) hari. Kerang ghiwo merupakan jenis kerang dengan frekuensi pemanfaatan yang tergolong intens, rata-rata nelayan pengumpul kerang-kerangan mencapai $1.800 \mathrm{~kg}$ per tahun.

\subsubsection{Jenis Pemanfaatan di Desa Wabintingi}

Nilai rata-rata pemanfaatan hutan mangrove diperoleh berdasarkan nilai pemanfaatan rata-rata nelayan, disajikan pada Tabel 8.

Berdasarkan Tabel 8, beberapa jenis pemanfaatan di areal hutan mangrove

Tabel 8. Jenis Kegiatan Pemanfaatan Langsung dari Sumberdaya Hutan Mangrove di Desa Wabinting, Kecamatan Lohia, Kabupaten Muna.

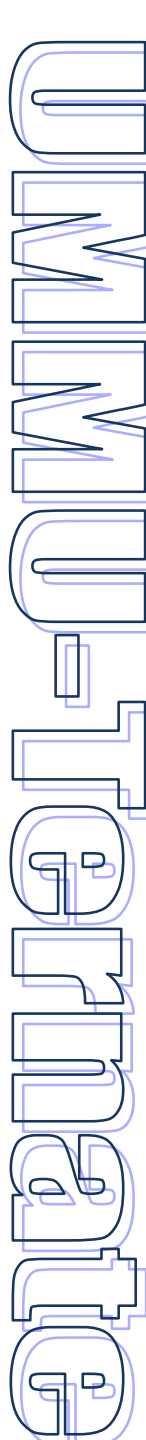

\begin{tabular}{|c|c|c|}
\hline No & Jenis Kegiatan Pemanfaatan & Rata-rata Pemanfaatan Pertahun \\
\hline 1 & Atap bangunan & 2.440 lembar \\
\hline 2 & Kepiting & $256 \mathrm{~kg}$ \\
\hline 3 & Udang & $248 \mathrm{~kg}$ \\
\hline 4 & Ikan & $7.292 \mathrm{~kg}$ \\
\hline 5 & Kerang-kerangan & $408 \mathrm{~kg}$ \\
\hline
\end{tabular}

Sumber : data primer penelitian.

Manfaat kepiting, yakni kepiting rajungan dan kepiting bakau rata-rata mencapai $256 \mathrm{~kg}$ per tahun. Manfaat udang, berupa udang putih dan udang windu, rata-rata pemanfaatan mencapai $248 \mathrm{~kg}$ per tahun. Manfaat ikan rata-rata pemanfaatan mencapai $7.292 \mathrm{~kg}$ per tahun. Manfaat kerang-kerangan, rata-rata responden nelayan pengumpul kerang-kerangan mencapai $408 \mathrm{~kg}$ per tahun.

\subsection{Nilai Ekonomi Hutan Mangrove}

3.3.1. Penilaian Ekonomi Hutan Mangrove

a. Manfaat Langsung

Kondisi aktual pada saat penelitian, luas hutan mangrove di Desa Wabintingi mencapai 10 ha. Sementara itu, luas hutan mangrove di Desa Labone mencapai 270 ha. Nilai manfaat langsung hutan mangrove dihitung dengan pendekatan pasar (Market Bassed Approach) menurut tingkat produktivitas pemanfaatan (Productivity Approach). Hasil rekapitulasi jenis dan nilai manfaat sumberdaya perikanan di kawasan hutan mangrove Desa Labone Kecamatan Lasalepa berdasarkan total biaya, nilai manfaat (keuntungan) (Tabel 9). bervegetasi Soneratia alba, Rhizophora apiculata dan Bruguera sp. merupakan jenis pemanfaatan hasil perikanan. Bentuk pemanfaatan tersebut berupa penangkapan kepiting, udang, ikan dan kerang-kerangan. Pengambil manfaat juga berasal dari di luar kawasan hutan mangrove Desa Wabintingi. Bentuk kegiatan pemanfaatan adalah pengambilan daun nipa sebagai bahan atap bangunan. Kegiatan tersebut dalam kondisi relatif terkendali, rata-rata jumlah pemanfaatan mencapai 2.440 lembar per tahun (Tabel 8). 


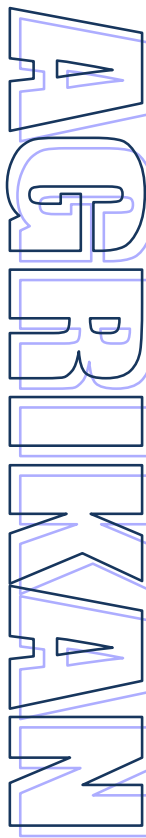

Jumlah pemanfaat sebanyak 2 KK dengan nilai produksi sebesar $\mathbf{1 . 2 0 0}$ lembar per tahun atau rata-rata sebesar 600 lembar per tahun per KK. Manfaat kepiting dengan keuntungan sebesar Rp.8.932.000,- per tahun atau sebesar Rp.33.081,per hektar per tahun, dengan biaya pemanfaatan sebesar Rp.758.000,- dengan nilai produksi sebesar $57 \mathrm{~kg}$ per tahun (Lampiran 10). Manfaat ikan diperoleh keuntungan sebesar Rp.31.660.000,- per tahun atau sebesar Rp.117.259,- per hektar per tahun, dengan biaya pemanfaatan sebesar Rp.14.840.000,-. Jumlah pemanfaat ikan sebanyak 3 KK dengan nilai

produksi sebanyak $2.325 \mathrm{~kg}$ per tahun atau ratarata sebesar $775 \mathrm{~kg}$ per tahun per KK. Manfaat kerang-kerangan, masyarakat Desa Labone dikenal sebagai pemasok ghiwo (kerang lumpur), dengan nilai keuntungan mencapai Rp.21.500.000,- per tahun atau sebesar Rp.79.630,- per hektar per tahun, dengan biaya pemanfaatan sebesar Rp.14.500.000,- per tahun.

Berdasarkan uraian tersebut di atas, secara keseluruhan nilai manfaat langsung (ML) hutan mangrove di Desa Labone (luas hutan 270 ha) sebesar Rp.158.226.314,- per tahun atau sebesar Rp.586.023,- per hektar per tahun (Gambar 6).

Tabel 9. Nilai Ekonomi Manfaat Langsung Hutan Mangrove Berdasarkan Pemanfaatan Aktual di Desa Labone Kecamatan Lasalepa, Tahun 2013.

\begin{tabular}{|c|c|c|c|c|}
\hline \multirow[t]{2}{*}{ No } & \multirow[t]{2}{*}{ Jenis Manfaat } & \multirow{2}{*}{$\begin{array}{l}\text { Biaya Total } \\
\text { (Rp/tahun) }\end{array}$} & \multicolumn{2}{|c|}{$\begin{array}{l}\text { Nilai Manfaat Desa Labone } \\
\text { (Luas Hutan } 270 \text { ha) }\end{array}$} \\
\hline & & & (Rp/tahun) & (Rp/ha/tahun) \\
\hline 1. & Pasir & 23.450 .000 & 66.550 .000 & 246.481 \\
\hline 2. & Atap bangunan & 234.200 & 1.445 .800 & 5.355 \\
\hline 3. & Kayu bakar & 2.692 .286 & 28.138.514 & 104.217 \\
\hline 4. & Kepiting & 758.000 & 8.932 .000 & 33.081 \\
\hline 5. & Ikan & 14.840 .000 & 31.660 .000 & 117.259 \\
\hline 6. & Kerang-kerangan & 14.500 .000 & 21.500 .000 & 79.630 \\
\hline & Total & 56.474 .486 & 158.226.314 & 586.023 \\
\hline
\end{tabular}

Sumber : data primer penelitian.

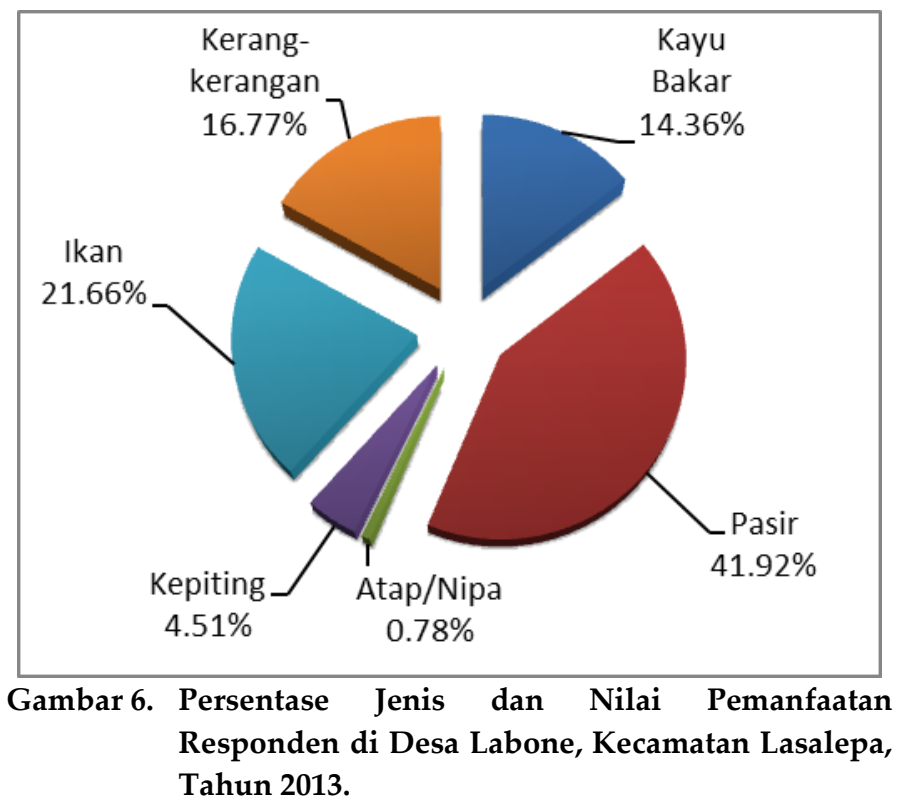

Hasil rekapitulasi pemanfaatan langsung di Desa Wabintingi dapat dilihat pada Tabel 10.

Berdasarkan Tabel 10, diketahui jenis manfaat langsung pengrajin atap nipa memperoleh keuntungan sebesar Rp.9.883.800,- per tahun atau sebesar Rp.988.380,- per hektar per tahun, dengan biaya total mencapai Rp.364.200 per tahun, dengan jumlah pemanfaat sebanyak 3 
(tiga) $K K$, nilai produksi sebanyak 7.230

lembar per tahun atau rata-rata sebesar 2.440 lembar per tahun per KK. Manfaat kepiting berupa kepiting rajungan dan kepiting bakau memperoleh keuntungan sebesar Rp.126.922.857,- per tahun atau sebesar Rp.12.692.286,- per hektar per tahun, dengan biaya total mencapai Rp.3.637.000,- per tahun. Jumlah pemanfaat kepiting sebanyak 3 (tiga) KK, nilai produksi sebesar $768 \mathrm{~kg}$ per tahun atau rata-rata sebesar $256 \mathrm{~kg}$ per KK per tahun. Harga jual kepiting per kilogram mengalami fluktuasi pada setiap saat berkisar antara Rp.110.000-Rp.170.000,-, ketika penelitian dilaksanakan, harga jual kepiting bakau mencapai Rp.170.000,- per kg. Hasil tangkapan kepiting bakau dijual pada pedagang pengumpul sehingga memiliki harga jual tinggi.

Tabel 10. Nilai Ekonomi Manfaat Langsung Hutan Mangrove Berdasarkan Pemanfaatan Aktual di Desa Wabintingi, Tahun 2013.

\begin{tabular}{|c|c|c|c|c|c|}
\hline & & \multirow[t]{2}{*}{ Jenis Manfaat } & \multirow{2}{*}{$\begin{array}{l}\text { Biaya Total } \\
\text { (Rp/tahun) }\end{array}$} & \multicolumn{2}{|c|}{$\begin{array}{l}\text { Nilai Manfaat Desa Wabintingi } \\
\text { (Luas Hutan } 10 \mathrm{ha} \text { ) }\end{array}$} \\
\hline & & & & \multirow{2}{*}{$\frac{(\text { Rp/tahun) }}{9.883 .800}$} & (Rp/ha/tahun) \\
\hline \multicolumn{2}{|c|}{$\begin{array}{l}\text { No } \\
1 .\end{array}$} & \multirow{2}{*}{$\begin{array}{l}\text { Atap bangunan (Nipa) } \\
\text { Kepiting }\end{array}$} & 364.200 & & 988.380 \\
\hline \multirow{3}{*}{$\square$} & 2. & & 3.637 .000 & 126.922 .857 & \multirow{2}{*}{$\begin{array}{l}12.692 .286 \\
13.601 .894\end{array}$} \\
\hline & 3. & Udang & 3.091 .060 & \multirow{2}{*}{\multicolumn{2}{|c|}{$\begin{array}{l}136.018 .940 \\
584.658 .278\end{array}$}} \\
\hline & 4. & lkan & 108.941 .722 & & \\
\hline & 5. & Kerang-kerangan & 1.053 .000 & 1.395 .000 & 139.500 \\
\hline & \multicolumn{2}{|r|}{ Total } & 975.966 .000 & 858.878 .876 & 85.887 .888 \\
\hline
\end{tabular}

Sumber : data primer penelitian.

Manfaat penangkapan udang berupa udang putih dan udang windu dengan nilai keuntungan sebesar Rp.13.601.894,- per hektar per tahun atau sebesar Rp.136.018.940,- per tahun dengan biaya total sebesar Rp.3.091.060,per tahun. Jumlah pemanfaat udang mencapai $10 \mathrm{KK}$, nilai produksi mencapai $2.478 \mathrm{~kg}$ per tahun atau rata-rata sebesar $248 \mathrm{~kg}$ per pemanfaat per tahun. Harga jual udang relatif bervariasi antara Rp.45.000 - Rp.65.000,- per kg. Manfaat ikan tergolong tinggi dengan jumlah keuntungan mencapai Rp.58.465.828,- per hektar per tahun atau sebesar Rp.584.658.278,per tahun, biaya total mencapai Rp.108.941.772,per tahun. Harga jual ikan bervariasi antara Rp.3.125 - Rp.100.000,- per kg. Jumlah pemanfaat ikan sebanyak $13 \mathrm{KK}$ dengan total produksi mencapai $94.800 \mathrm{~kg}$ atau rata-rata sebesar 7.272 kg per KK (Lampiran 15). Sementara itu jenis pemanfaatan kerangkerangan diperoleh keuntungan sebesar Rp.1.395.000,- per tahun atau sebesar Rp.139.500,- per hektar per tahun, dengan total biaya produksi sebesar Rp.1.053.000,--

Berdasarkan uraian di atas, secara keseluruhan nilai manfaat langsung (ML) ekosistem hutan mangrove di Desa Wabintingi (luas hutan 10 ha) sebesar Rp.858.878.876,- per tahun atau sebesar Rp.85.887.888,- per hektar per tahun (Gambar 7).

Berdasarkan Gambar 17 tersebut di atas, diketahui bahwa jenis manfaat perikanan di kawasan hutan mangrove di Desa Wabintingi dengan persentase tertinggi ke rendah secara berturut-turut adalah manfaat ikan $(68,07 \%)$, manfaat udang $(15,84 \%)$, manfaat kepiting $(14,78 \%)$, manfaat atap $(1,15 \%)$ dan manfaat kerang-kerangan $(0,16 \%)$.

Untuk mengetahui perbandingan antara jenis dan nilai pemanfaatan langsung aktual di Desa Labone dan Desa Wabintingi, disajikan pada Tabel 11.

Diketahui total nilai manfaat langsung di Desa Wabintingi mencapai Rp.97.596.600,- per hektar per tahun, sementara di Desa Labone mencapai Rp.586.023,- per hektar per tahun. Hal ini bermakna bahwa nilai produktivitas hutan mangrove Desa Wabintingi jauh lebih tinggi dibandingkan dengan hutan mangrove di Desa Labone, oleh karena luasan hutan mangrove di Desa Wabintingi tergolong kecil yakni 10ha sementara di Desa Labone mencapai seluas 270ha (Gambar 8 ). 

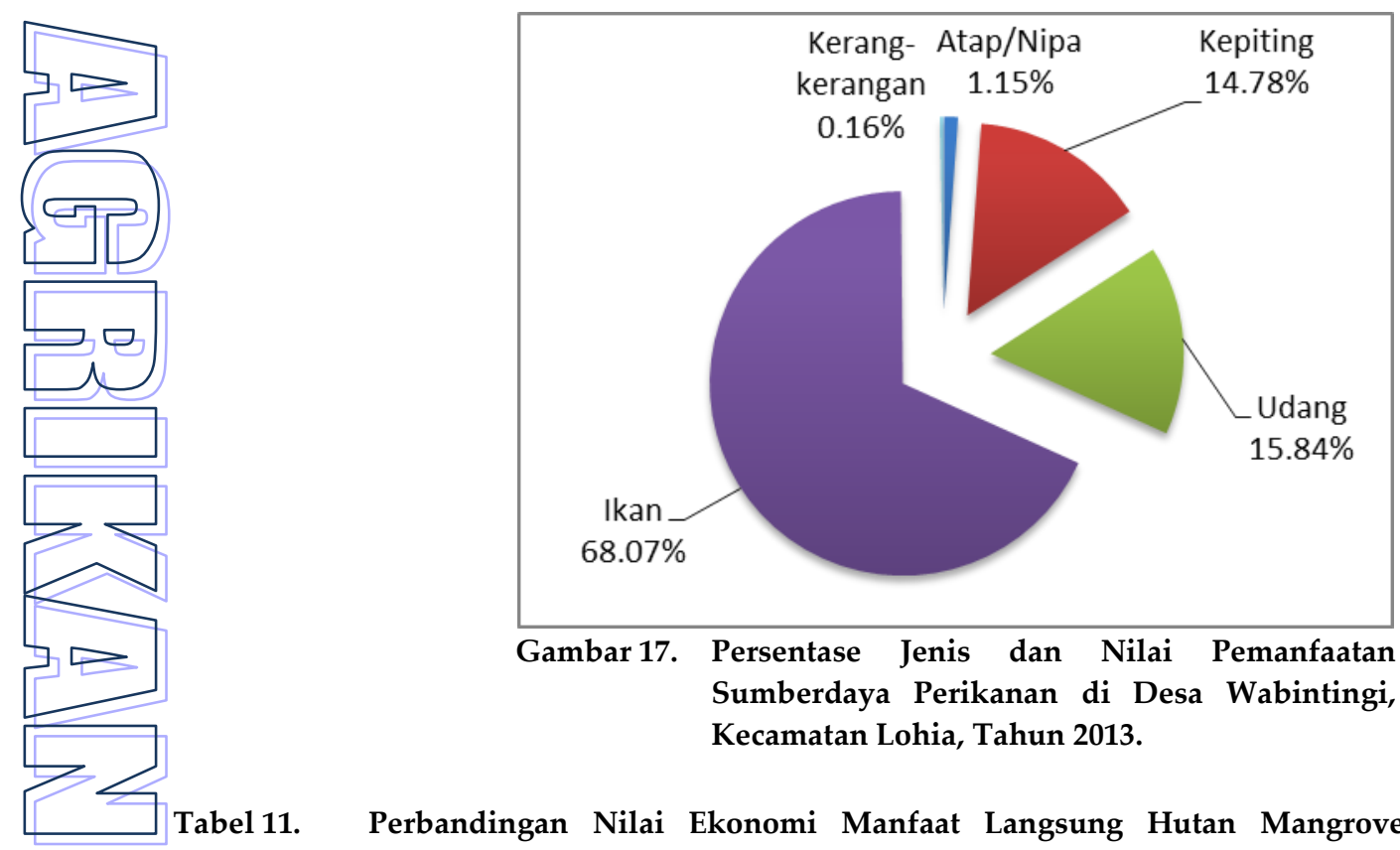

Gambar 17. Persentase Jenis dan Nilai Pemanfaatan Sumberdaya Perikanan di Desa Wabintingi, Kecamatan Lohia, Tahun 2013.

Tabel 11. Perbandingan Nilai Ekonomi Manfaat Langsung Hutan Mangrove di Desa Wabintingi Kecamatan Lohia dan Desa Labone Kecamatan Lasalepa, Tahun 2013.

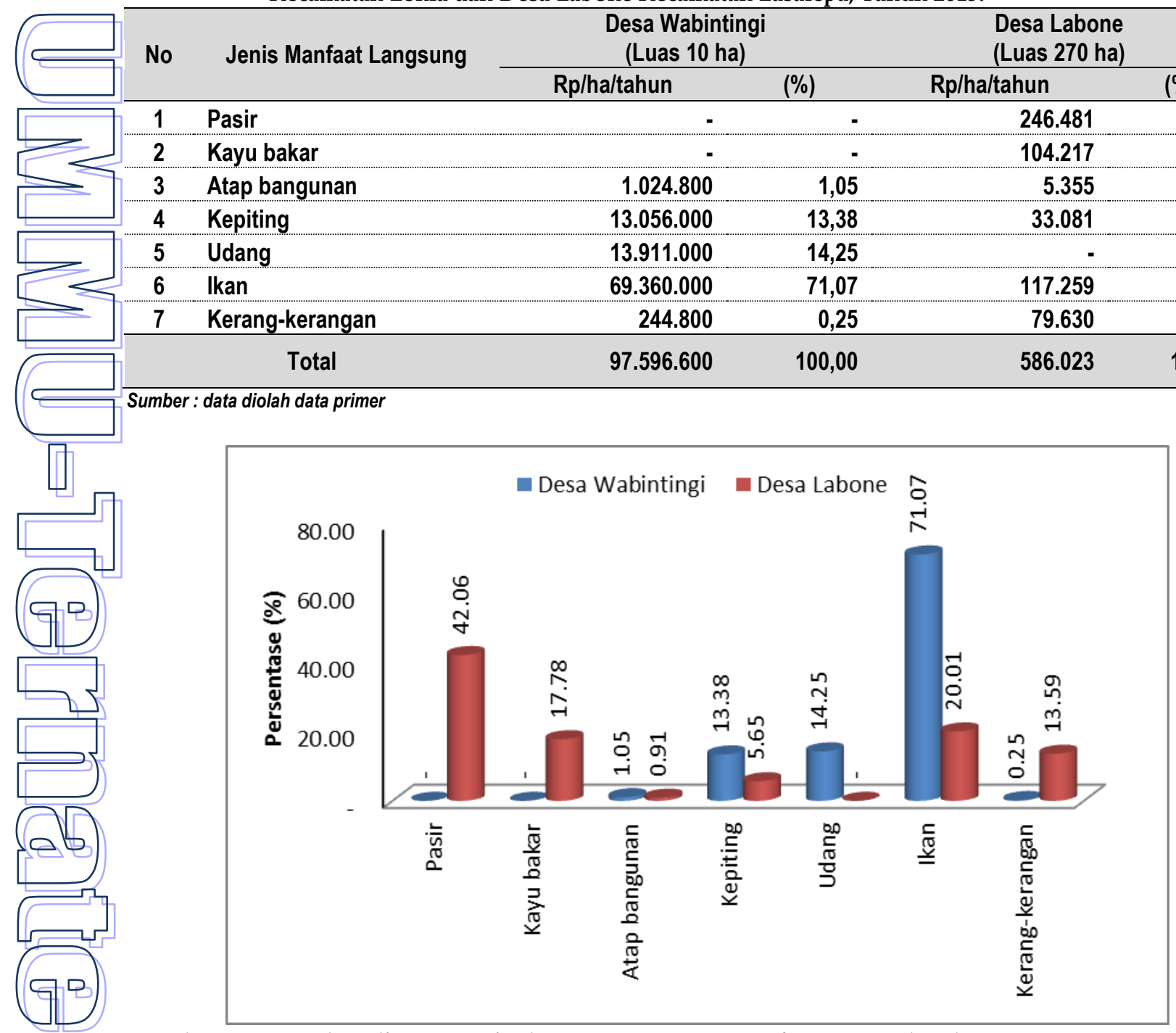

Gambar 18. Perbandingan Jenis dan Persentase Pemanfaatan Sumberdaya Hutan Mangrove Desa Wabintingi Kecamatan Lohia dan Desa Labone, Kecamatan Lasalepa, Tahun 2013. 
Diketahui jenis manfaat perikanan di kawasan hutan mangrove Desa Wabintingi dengan persentase tertinggi ke rendah secara berturut-turut adalah manfaat pasir $(41,92 \%)$, manfaat ikan $(21,66 \%)$, manfaat kerangkerangan $(16,77 \%)$, manfaat kayu bakar $(14,36 \%)$ dan manfaat kepiting $(4,51 \%)$ dan manfaat atap bangunan (0,78\%). Sementara itu, nilai ekonomi manfaat langsung antara Desa Wabintingi dan Desa Labone relatif memiliki perbedaan yang sangat jauh.

Berdasarkan hasil analisis vegetasi dan nilai ekonomi manfaat langsung di atas diduga terdapat hubungan yang relatif erat antara kondisi vegetasi hutan mangrove dengan nilai ekonomi pemanfaatan sumberdaya hutan (Gambar 18). Dugaan ini menjadi semakin kuat dengan dasar nilai ekonomi manfaat langsung dan luasan hutan mangrove di kedua lokasi yang berbeda. Hasil penelitian Paena dan Asbar (2003), Suryono (2006), Apung (2011), Suzana, L. dkk (2011) dan Qodrina, L. dkk (2012), secara gamblang mengatakan bahwa ekosistem hutan mangrove yang berada dalam kondisi yang baik akan meningkatkan nilai ekonomi pendapatan masyarakat yang memanfaatkan hasil perikanan di sekitar hutan mangrove tersebut.

\subsubsection{Manfaat Tidak Langsung}

Manfaat tidak langsung dihitung berdasarkan 3 (tiga) fungsi utama hutan mangrove, yakni manfaat fisik, manfaat biologis dan manfaat ekologis (Suryono, 2006). Manfaat fisik dihitung dengan mengestimasi nilai pembuatan bangunan air berupa pemecah gelombang/ombak (break water). Sementara manfaat biologis didekati dengan fungsi sebagai tempat pemijahan, pembesaran dan asuhan berbagai jenis ikan dan udang serta penyedian bahan organik bagi kelangsungan organime khususnya bagi organisme crustacea (hewan bercangkang/udang-udangan). Sementara menfaat ekologis diestimasi dengan pendekatan jumlah serapan karbon.

Hasil perhitungan nilai ekonomi manfaat tidak langsung hutan mangrove di Desa Labone dan Desa Wabintingi, disajikan pada Tabel 12.

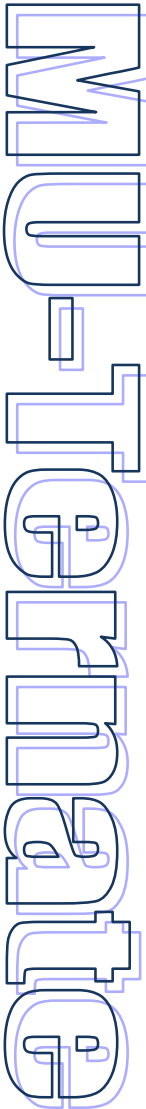

Tabel 12. Perbandingan Nilai Ekonomi Manfaat Tidak Langsung Hutan Mangrove di Desa Wabintingi Kecamatan Lohia dan Desa Labone Kecamatan Lasalepa, Tahun 2013.

\begin{tabular}{|c|c|c|c|c|c|}
\hline \multirow{3}{*}{ No } & \multirow{3}{*}{ Jenis Manfaat } & \multicolumn{4}{|c|}{ Nilai Manfaat } \\
\hline & & \multicolumn{2}{|c|}{ Desa Wabintingi } & \multicolumn{2}{|c|}{ Desa Labone } \\
\hline & & Rp/tahun & Rp/ha/tahun & Rp/tahun & Rp/ha/tahun \\
\hline 1. & Penahan abrasi & 688.000 .000 & 45.866 .667 & 1.857 .600 .000 & 123.840 .000 \\
\hline 2. & $\begin{array}{l}\text { Penjaga kestabilan rantai } \\
\text { makanan }\end{array}$ & 1.864 .500 & 186.450 & 50.341 .500 & 186.450 \\
\hline 3. & Penyerap karbon & 6.263 .297 & 626.330 & 169.109 .020 & 626.330 \\
\hline & Total & 696.127.797 & 46.679 .447 & 2.077 .050 .520 & 124.652 .780 \\
\hline
\end{tabular}

Sumber : diolah dari data primer penelitian.

Nilai ekonomi penahan abrasi pantai dengan penggunaan bangunan pemecah gelombang, menurut nilai dasar perhitungan bangunan oleh Dinas Pekerjaan Umum Kabupaten Muna, dengan ukuran panjang $1 \mathrm{~m}$, lebar $1 \mathrm{~m}$ dan tinggi $2,5 \mathrm{~m}(1 \mathrm{~m} \times 1 \mathrm{~m} \times 2,5 \mathrm{~m})$ daya tahan 15 tahun sebesar Rp.688.000,-. Pemecah gelombang sebagai penahan abrasi pantai dibuat sepanjang pantai. Untuk Desa Wabintingi, panjang pantai $1000 \mathrm{~m}$, biaya yang dibutuhkan untuk pembuatan pemecah gelombang sebesar Rp.688.000.000,-. Sementara panjang pantai Desa Labone $2700 \mathrm{~m}$, biaya yang dibutuhkan sebesar Rp.1.857.600.000,- (Tabel 12).
Sebagai penjaga kestabilan siklus makanan pada ekosistem hutan mangrove, didekati dengan nilai unsur hara yang dihasilkan berupa serasah mangrove sebagai penunjang produktivitas ekosistem (Suryono, 2006; Apung, 2011). Setiap hektar hutan mangrove mampu mengahasilkan serasah sebanyak 13,8 ton per tahun atau setara 4,85 ton berat kering per tahun (Sukardjo, 1995 dalam Suryono, 2006) dan Apung (2011), mengandung hara Nitrogen $(N)$ 10,5 kg per hektar atau setara $23,33 \mathrm{~kg}$ pupuk Urea, dan hara fosfor $4,72 \mathrm{~kg}$ per hektar atau setara 13,11 kg pupuk SP-36. Jika asumsi harga pupuk Urea sebesar Rp.11.000,- dan SP-36 sebesar Rp.15.000,-, maka nilai ekonomi serasah yang dihasilkan sebesar 
Rp.186.450,- per hektar. Dengan demikian, nilai ekonomi manfaat penjaga siklus makanan di Desa Wabintingi (luas 10 ha) sebesar Rp.1.864.500,- per tahun, sementara Desa Labone (luas 270 ha) sebesar Rp.50.341.500,- per tahun (Tabel 12).

Manfaat ekologis penyerap karbon jenis Rhizophora sp. dengan potensi nilai karbon berkisar 3.258,34 - 3.957,44 kg per hektar, asumsi nilai rata-rata sebesar $3.607,89 \mathrm{~kg}$ per hektar (Suryono, 2006; Apung, 2011). Harga 1 ton karbon sebesar UD\$ 15,5 atau sebesar Rp.173.600,- (asumsi nilai kurs 1 US\$ = Rp.11.200,-). Dengan demikian, total nilai karbondioksida yang tersimpan di hutan mangrove mencapai Rp.626.330,- per hektar per tahun. Dengan dasar tersebut, maka jumlah nilai ekonomi serapan karbon di Desa Wabintingi (luas 10 ha) Rp.6.263.297,-- per tahun, sementara di Desa Labone (luas 270 ha) Rp.169.109.020,- per tahun (Tabel 12).

Nilai ekonomi manfaat tidak langsung sebagai penahan abrasi pantai sebagai fungsi fisik, sebagai penjaga siklus makanan sebagai fungsi biologis dan sebagai penyerap karbon sebagai fungsi ekologis antara hutan mangrove di Desa Wabintingi dan Desa Labone relatif berbeda. Perbedaan tersebut sangat terkait dengan luas hutan mangrove itu sendiri sebagai faktor pengganda nilai ekonomi hutan mangrove per satuan hektarnya. Selain itu dapat dikatakan bahwa semakin besar luas suatu kawasan hutan mangrove, maka nilai ekonomi manfaat tidak langsung dari ekosistem hutan tersebut semakin tinggi.

\subsubsection{Manfaat Pilihan}

Manfaat pilihan didekati dengan nilai keanekaragaman hayati (biodiversity). Menurut Suryono (2006), manfaat pilihan merupakan jenis pemanfaatan yang mencerminkan nilai keanekaragaman hayati (biodiversity) yang dapat ditangkap dari keberadaan hutan mangrove. Ruitenbeek (1992) mengatakan bahwa nilai keanekaragaman hayati (biodivesity) hutan mangrove di Indonesia khususnya di Teluk Bintani, Irian Jaya, Papua adalah sebesar US\$ 1.500 per km² per tahun atau US\$ 15 per hektar per tahun.

Nilai manfaat pilihan hutan mangrove Desa Wabintingi (luas 10 ha) sebesar Rp.1.680.000,- per tahun atau sebesar Rp.140.000,- per hektar per tahun (asumsi kurs 1 US\$ = Rp.11.200,-), sementara Desa Labone (luas 270ha) sebesar Rp.45.360.000,- per tahun atau sebesar Rp.3.780.000,-- per hektar per tahun.

\subsubsection{Manfaat Keberadaan}

Manfaat keberadaan hutan mangrove Desa Wabintingi maupun Desa Labone, diperoleh dengan teknik valuasi yang di dasarkan atas survey untuk mengetahui keinginan membayar atau WTP (Willingnes to Pay) masyarakat.

Hasil wawancara dan survey di Desa Labone kecamatan Lasalepa dan Desa Wabintingi kecamatan Lohia ditabulasi untuk mendapatkan total nilai WTP, rata-rata dan nilai manfaat keberadaan per individu per tahun maupun nilai manfaat keberadaan per hektar per tahun (Tabel 13).

Tabel 13. Hasil Kuatifikasi Nilai Manfaat Keberadaan Hutan Mangrove di Desa Labone Kecamatan Lasalepa dan Desa Wabintingi Kecamatan Lohia, Tahun 2013.

\begin{tabular}{lrr}
\hline \multicolumn{1}{c}{ Indikator Penilaian } & Desa Labone & Desa Wabintingi \\
\hline Responden & 37 & 34 \\
Luas Hutan (ha) & 270 & 10 \\
Total Nilai WTP & 76.150 .000 & 82.000 .000 \\
Rata-rata WTP (Rp/ha/tahun) & 2.058 .108 & 2.411 .765 \\
Nilai Manfaat (Rp/tahun) & 555.689 .189 & 24.117 .647 \\
\hline
\end{tabular}

Sumber : Data diolah dari Lampiran 6 dan 7.

Hasil rekapitulasi jawaban responden (Tabel 13 dan Lampiran 6) nilai rata-rata manfaat keberadaan hutan mangrove Desa Labone sebesar Rp.2.058.108 per hektar per tahun. Nilai tersebut dikalikan dengan luas hutan mangrove di Desa Labone (270 ha), diperoleh total manfaat keberadaan sebesar Rp.555.689.189 per tahun, sementara di Desa Wabintingi (10 ha), nilai manfaat sebesar Rp.24.117.647,- per tahun atau sebesar Rp.2.411.765,- per hektar per tahun (Tabel 13 dan Lampiran 7). Nilai manfaat keberadaan 
hutan mangrove Desa Labone lebih tinggi dibanding nilai manfaat keberadaan hutan mangrove Desa Wabintingi.

\subsubsection{Nilai Ekonomi Total Hutan Mangrove}

Berdasarkan hasil identifikasi dan kuantifikasi seluruh manfaat, maka nilai ekonomi total hutan mangrove di Desa Labone Kecamatan Lasalepa dan Desa Wabintingi Kecamatan Lohia, dapat dilihat pada Tabel 14.

Total nilai ekonomi hutan mangrove Desa Labone Kecamatan Lasalepa mencapai Rp.131.076.911,- per hektar per tahun atau sebesar Rp.2.836.335.023,- per tahun, nilai manfaat tidak langsung memberi sumbangan terbesar 95,10\% atau Rp.124.652.780,- per hektar per tahun atau Rp.2.077.050.520,- per tahun.

Tabel 14. Kuantifikasi Manfaat Ekonomi Hutan Mangrove di Desa Labone Kecamatan Lasalepa dan Desa Wabintingi Kecamatan Lohia, tahun 2013.
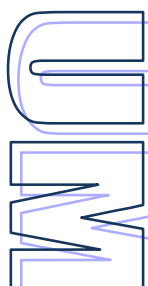

No.

Jenis Manfaat

\section{Desa Labone}

Desa Wabintingi

\begin{tabular}{rlrrrr}
\cline { 3 - 5 } & & (Rp/ha/thn) & \multicolumn{1}{c}{ (Rp/thn) } & \multicolumn{1}{c}{ (Rp/ha/thn) } & \multicolumn{1}{c}{ (Rp/thn) } \\
\hline 1 & Manfaat Langsung & 586.023 & 158.226 .314 & 85.887 .888 & 858.878 .876 \\
\hline 2 & Manfaat Tidak Langsung & 124.652 .780 & 2.077 .050 .520 & 46.767 .447 & 696.127 .797 \\
\hline 3 & Manfaat Pilihan & 3.780 .000 & 45.360 .000 & 140.000 & 1.680 .000 \\
\hline 4 & Manfaat Keberadaan & 2.058 .108 & 555.689 .189 & 2.411 .765 & 24.117 .647 \\
\hline & Total Nilai Manfaat & 131.076 .911 & 2.836 .335 .023 & 135.116 .100 & 1.580 .804 .320 \\
\hline
\end{tabular}

Sumber : Diolah dari data primer penelitian, 2013.

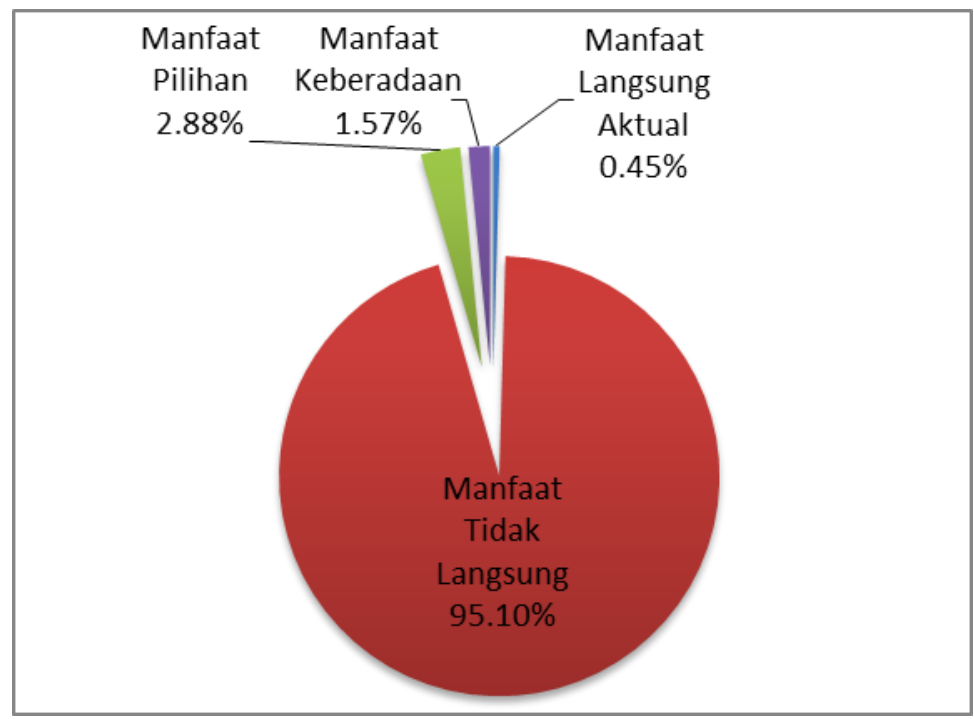

Gambar 19. Proporsi Nilai Ekonomi Total Hutan Mangrove di

Desa Labone Kecamatan Lasalepa, tahun 2013.

Proporsi nilai ekonomi total hutan mangrove Desa Wabintingi Kecamatan Lohia sebagaimana disajikan pada Gambar 20. Total nilai ekonomi hutan mangrove Desa
Wabintingi mencapai Rp.135.116.100,- per hektar per tahun atau Rp.1.580.804.320,- per tahun. Manfaat ekonomi dengan nilai sumbangan terbesar adalah jenis manfaat 


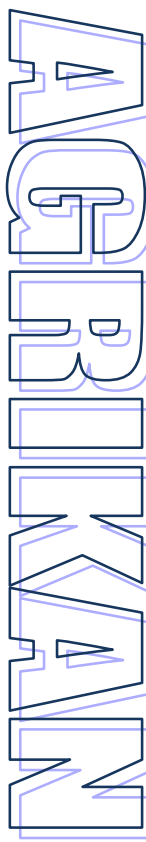

langsung aktual 63,57\% atau Rp.85.887.888,- per hektar per tahun atau Rp.858.878.876,- per tahun. Manfaat tidak langsung $34,55 \%$ atau Rp.46.767.447,- per hektar per tahun atau Rp.696.127.797,- per tahun. Manfaat keberadaan dan manfaat pilihan, masing-masing memberi sumbangan 1,78\% atau Rp.2.411.765,- per hektar per tahun atau Rp.24.117.647,- per tahun dan 0,10\% atau Rp.140.000,- per hektar per tahun atau Rp.1.680.000,- per tahun.

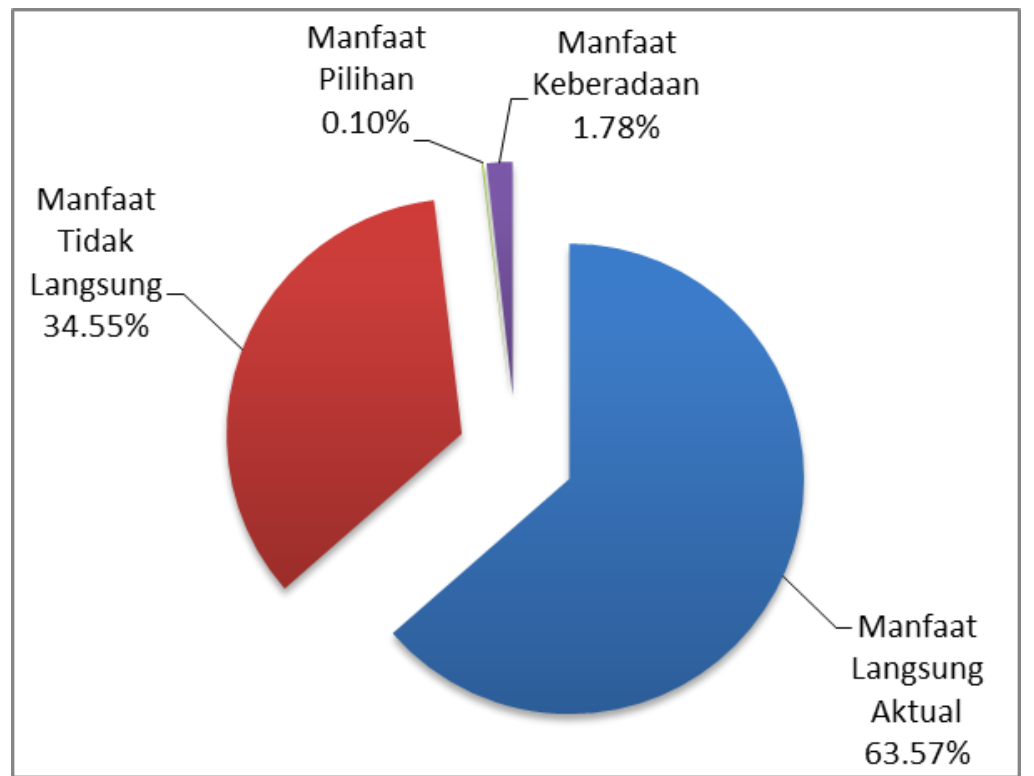

Gambar 20. Proporsi Nilai Ekonomi Total Hutan Mangrove di Desa Wabintingi Kecamatan Lohia, tahun 2013.

Nilai total manfaat hutan mangrove Desa Labone lebih kecil dibandingkan dengan nilai total manfaat hutan mangrove Desa Wabintingi. Hal tersebut dicerminkan oleh nilai manfaat langsung di kedua lokasi yang berbeda. Ini menegaskan bahwa nilai ekonomi yang dihasilkan dari pemanfaatan sumberdaya hutan mangrove di kedua lokasi tersebut relatif terkait erat dengan kondisi vegetasi hutan mangrove itu sendiri. Implikasi dari kondisi tersebut yakni hutan mangrove Desa Wabintingi memiliki nilai ekonomi yang cukup tinggi dengan kondisi vegetasi baik, sehingga ketersediaan dan kesinambungan (sustainability) dari sumberdaya alam tersebut menjadi sangat penting bagi ekonomi masyarakat Desa Wabintingi khususnya dan Kecamatan Lohia umumnya. Sementara hutan mangrove Desa Labone memiliki nilai ekonomi yang cukup rendah dengan kondisi vegetasi rusak, sehingga masyarakat melakukan tindakan pemanfaatan yang cenderung destruktif oleh karena hutan mangrove tidak lagi menyediakan usmberdaya perikanan yang memadai dalam menopang ekonomi masyarakat desa Labone. Dengan demikian, perlunya langkah perbaikan hutan mangrove baik itu dilakukan oleh masyarakat, lembaga penelitian atau pendidikan maupun pemerintah.

\section{P E N U T U P}

\subsection{Kesimpulan}

Berdasarkan hasil dan pembahasan yang telah dilakukan, maka dapat disimpulkan sebagai berikut;

1. Vegetasi hutan mangrove Desa Labone Kecamatan Lasalepa tergolong rusak, tingkat kerapatan jarang, didominasi vegetasi tumbuhan baru. Vegetasi hutan mangrove Desa Wabintingi Kecamatan Lohia tergolong baik tingkat kerapatan jarang, didominasi oleh vegetasi tumbuhan berusia tua.

2. Jenis pemanfaatan langsung sumberdaya hutan mangrove Desa Labone meliputi penambangan pasir, pengrajin atap bangunan dari daun nipa, pengambil kayu bakar komersial, penangkap kepiting, penangkap ikan dan pengumpul kerangkerangan. Jenis pemanfaatan Desa Wabintingi meliputi pengrajin atap 


bangunan dari daun nipa, penangkap
kepiting, penangkap udang, penangkap
ikan dan pengumpul kerang-kerangan.
Nilai ekonomi total hutan mangrove Desa
Labone per hektar per tahun lebih tinggi
dibandingkan dengan nilai ekonomi total
per hektar per tahun hutan mangrove Desa
Wabintingi. Sumbangan nilai ekonomi
hutan mangrove Desa Labone terbesar
disumbangkan jenis manfaat tidak
langsung, sementara sumbangan ekonomi
manfaat langsung lebih kecil. Nilai
ekonomi total hutan mangrove Desa
Wabintingi, lebih besar disumbangkan
oleh jenis manfaat langsung.

\section{2. $S$ a r a n}

Berdasarkan kesimpulan tersebut di atas, maka disarankan agar :

1. Dilakukan penelitian lebih lanjut di lokasi lain guna memberi informasi penting kepada pengambil kebijakan terkait pengelolaan kawasan hutan mangrove di Kabupaten Muna, dengan menggunakan pendekatan dan metode lain..

2. Pemerintah Kabupaten Muna diharapkan melakukan upaya perbaikan dan peningkatan kualitas fisik vegetasi hutan mangrove di kedua lokasi penelitian utamanya hutan mangrove Desa Labone Kecamatan Lasalepa yang telah mengalami kerusakan dan menjaga kondisi vegetasi hutan mangrove Desa Wabinting Kecamatan Lohia.

Dilakukan penerapan teknologi digitasi (GIS), guna pemetaan kawasan hutan mangrove dengan tepat khususnya dalam menentukan luasan hutan mangrove, serta penerapan teknologi pembenihan dan penanaman kembali hutan mangrove dengan melibatkan stakeholder yakni Perguruan Tinggi, LSM, Pemerintah Daerah dan masyarakat sekitar hutan yang dikoordinir oleh Pemerintah Kabupaten Muna.

\section{UCAPAN TERIMA KASIH}

Kami mengucapkan terima kasih yang sebesarbesarnya atas kerjasama dari berbagai pihak. Kementerian Pendidikan dan Kebudayaan Republik Indonesia melalui Direktorat Penelitian dan Pengabdian Masyarakat (DP2M), Direktorat Jenderal Pendidikan Tinggi (DIKTI). Ibu Prof. Dr. Ir. Hj. Andi Niartiningsih, MP selaku Koordinator Kopertis Wilayah IX Sulawesi beserta jajarannya, Ketua LPPM STIP Wuna yang telah memberikan petunjuk dan arahannya, dan Komunitas "Kaghiwo" pengumpul kerang di Desa Langkolome Kecamatan Wakorumba Kabupaten Muna.

\section{DAFTAR PUSTAKA}

Adrianto L., Mujio dan Wahyudin Y., 2004, Modul Pengenalan Konsep dan Metodologi Valuasi Ekonomi Sumberdaya Pesisir dan Laut Pusat Kajian Sumberdaya Pesisir dan Laut Institut Pertanian Bogor (PKSPL- IPB) Bogor

Adrianto L., Fahrudin A., dan Wahyudin Y., 2007, Konsepsi Valuasi Ekonomi Sumberdaya Alam dan Lingkungan, Modul, disampaikan pada Pelatihan Teknik dan Metode Pengumpulan Data Valuasi Ekonomi, Kerjasama Pusat Kajian Sumberdaya Pesisir dan Laut IPB Bogor dengan Pusat Survey Sumberdaya Alam Laut BAKOSURTANAL, Bogor 5 - 9 Maret 2007.

Anonim. 2007. Data Luas Kawasan Mangrove Provinsi Sulawesi Tenggara, Balai Pengelolaan Hutan Wilayah I, Direktorat Jenderal Bina Pengelolaan Daerah Aliran Sungai (BPDAS) Sampara dan Perhutanan Sosial Departemen Kehutanan RI

Anonim. 2008. Laporan Tahunan Statistik Perikanan. Dinas Kealutan dan Perikanan Kabupaten Muna. Muna.

Anonim. 2012. Analisis Ekonomi Hutan Mangrove. Serial On-Line melalui http://203.116.43.77/publications/research1/ACF9E.html, diakses tanggal 10 Oktober 2012 
Anonim. 2012. Manfaat Dan Fungsi Mangrove. Serial On-line diakses melalui: http://bphm1.net/index.php?option=com_content\&view=article\&id=47\&Itemid=55, diakses tanggal 12 Mei 2012

Anonim. 2013. Pedoman Inventaritas Mangrove. Serial On-Line, diakses melalui : https://onrizal.files.wordpress.com/.../pedoman_inventarisasi_mangrove.... tanggal 30 April 2013.

Apung, A.N. 2011. Valuasi Ekonomi Pemanfaatan Hutan Mangrove di Kabupaten Barru, Sulawesi Selatan. Tesis. Program Pascasarjana Universitas Hasanuddin. Makassar.

Aqsa M., 2010, Rehabilitasi dan Konservasi Mangrove dalam Menunjang Kawasan Konservasi Laut Daerah (KKLD) Selat Tiworo. Artikel pribadi. Serial On-line, diakses melalui situs : http://mimpi22.wordpress.com/category/rehabilitasi-dan-konservasi-mangrove-sultra/ tanggal 12 Oktober 2012.

Baderan, 2013, Model Valuasi Ekonomi sebagai Dasar untuk Rehabilitasi Kerusakan Hutan Mangrove di Wilayah Pesisir Kecamatan Kwandang Kabupaten Gorontalo Utara Provinsi Gorontalo, Ringkasan Disertasi, Program Pascasarjana Fakultas Geografi Universitas Gadjah Mada Yogyakarta

Bengen, 2000. Sinopsis Ekosistem dan Sumberdaya Alam Pesisir. Pusat Kajian Sumberdaya Pesisir dan Lautan - Institut Pertanian Bogor. Bogor, Indonesia.

2002, Pedoman Pengumpulan dan Analisis Data Biofisik Ekosistem Pesisir, Makalah Pelatihan Integrated Coastal Zone Planning and Management (ICZPM) , Kerjasama Pusat Kajian Sumberdaya Pesisir dan Laut IPB Bogor dengan Dinas Perikanan dan Kelautan Kabupaten Muna, Kendari, 15 - 29 Agustus 2002.

2004. Pedoman Teknis Pengenalan dan Pengelolaan Ekosistem Mangrove. Pusat Kajian Sumberdaya Pesisir dan Lautan-Institut Pertanian Bogor.

Direktorat Jenderal Rehabilitasi Lahan dan Perhutanan Sosial (2005), Pedoman Inventarisasi dan Identifikasi Lahan Kritis Mangrove, Departemen Kehutanan RI, Jakarta

Fachrul, M.F., 2008. Metode Sampling Bioekologi. Penerbit PT. Bumi Aksara. Jakarta.

Fauzi, 2004, Ekonomi Sumberdaya Alam dan Lingkungan, Teori dan Aplikasi. Penerbit PT Gramedia Pustaka Utama, Jakarta

Gunarto, 2004, Konservasi Mangrove sebagai Pendukung Sumber Hayati Perikanan Pantai, Balai Riset Perikanan Budidaya Air Payau, Maros, Sulawesi Selatan, Jurnal Litbang Pertanian, 23(1), 2004

Harahab, H. 2011. Valuasi Ekonomi Ekosistem Hutan Mangrove Dalam Perencanaan Wilayah Pesisir. Jurnal Berk. Penelitian Hayati Edisi Khusus 7A. halaman 59-67.

Hiariey, L.S., 2009. Identifikasi Nilai Ekonomi Ekosistem Hutan Mangrove Di Desa Tawiri, Ambon. Jurnal Ilmiah Organisasi dan Manajemen. Volume 5, Nomor 1. Halaman 23-34.

Huda, 2008, Strategi Kebijakan Pengelolaan Mangrove Berkelanjutan di Wilayah Pesisir Kabupaten Tanjung Jabung Timur, Jambi, Tesis, Program Pascasarjana Universitas Diponegoro, Semarang.

IUCN, 2007, Environmental and Socio Economic Value of Mangroves in Tsunami Affected Areas Rapid Mangrove Valuation Study, Panama Village in South Eastern Coast of Sri Lanka

Keputusan Menteri Negara Lingkungan Hidup Nomor 201 Tahun 2004, Tentang Kriteria Baku Dan Pedoman Penentuan Kerusakan Mangrove, Publikasi On-line, melalui laman: www.dephut.go.id/files/P37_2010.pdf diakses tanggal 15 April 2013.

Kustanti, 2011, Manajemen Hutan Mangrove, IPB Press Bogor.

Macintosh and Ashton, 2002, Review of Mangrove Biodiversity Conservation and Management, The World Bank and Centre for Tropical Ecosystems Research (cenTER Aarhus), University of Aarhus, Denmark

Noor, Khazali, dan Suryadiputra, 2006, Panduan Pengenalan Mangrove di Indonesia, Kerjasama Ditjen PHK dengan Wetlands International Indonesian Programe, Bogor. 
Paena, M. dan Asbar. 2005. Valuasi Nilai Ekonomi Ekosistem Mangrove Swadaya Masyarakat Di Wilayah Pesisir Desa Tongke-Tongke Kabupaten Sinjai, Sulawesi Selatan. Jurnal Sains Akuatik. Volume 10, Edisi 1. Halaman 28-35.

Qadrina, L., Hamidy R, dan Zulkarnaini. 2012. Valuasi Ekonomi Ekosistem Mangrove Di Desa Teluk Pambang Kecamatan Bantan Kabupaten Bengkalis Provinsi Riau. Jurnal Ilmuah Ilmu Lingkungan. ISSN 1978-5283. 6(2).

Rahman., 2008. Koefisien Seret Gaya Gelombang pada APO dengan Tambahan Gedhek., Fakultas Teknik Universitas Hasanuddin, Makassar., Media Teknik Si pil/ Juli 2008.

Rochmady. 2011. Aspek Bioekologi Kerang Lumpur Anodontia edentula (Linnaeus, 1758) (Bivalvia; Lucinidae) Di Perairan Pesisir Kabupaten Muna. Tesis. Program Pascasarjana Universitas Hasanuddin. Makassar.

Ruitenbeek, H. Jack., 1992, Mangrove Management: An Economic Analysis of Management Options with a Focus on Bintuni Bay, Irian Jaya, Environmental Management Development in Indonesia Project (EMDI), Jakarta and Halifax, www.unepscs.org/Economic.../... Diakses tanggal 14 April 2013

Sathirathai, 2003, Economic Valuation of Mangroves and the Roles of Local Communities in the Conservation of Natural Resources: Case Study of Surat Thani, South of Thailand, Economy and Environment Program for Southeast Asia Research Reports.

Setyawan A., dan Winarno K., 2006. Pemanfaatan Langsung Ekosistem Mangrove Di Jawa Tengah Dan Penggunaan Lahan Di Sekitarnya; Kerusakan dan Upaya Restorasinya. Jurnal Biodivesitas ISSN.1412-033X. Volume 7, Nomor 3. Halaman 282-291

Sobari, Fauzi dan Iqbal, 2006, Analisis Nilai Ekonomi Taman Wisata Alam Laut Pulau Weh di Kota Sabang, Mangrove dan Pesisir Vol. VI No. 3/2006.

Sobari, M.P., Adrianto, L., dan Azis N. 2006. Analsis Ekonomi Alternatif Pengelolaan Ekosistem Mangrove Kecamatan Barru, Kabupaten Barru. Bulietin Ekonomi Perikanan. Volume VI, Nomor 3.

Spaninks,, dan Beukering, 1997, Economic Valuation of Mangrove Ecosystems: Potential and Limitations, CREED Working Paper No 14

Subade, 2005 Valuing Biodiversity Conservation in a World Heritage Site: Citizens' Non-Use Values For Tubbataha Reefs National Marine Park, Philippines, Research report, ISSN 1608-5434, 2005-RR4, Co-published by the International Development Research Centre. Includes Bibliographical References, ISBN 1-55250-165-5 www.eepsea.org, diakses tanggal 13 Januari 2013.

Suhelmi, 2003, Ekonomi Lingkungan dan Pengelolaan Sumberdaya Berkelanjutan, Prosiding Lokakarya Nasiomal, Menuju Pengelolaan Sumberdaya Wilayah Berbasis Ekosistem untuk Mereduksi Potensi Konflik Antar Daerah, Halaman 176 - 191.

Suryono, T. 2006. Penilaian Ekonomi Lingkungan Terhadap Konversi Hutan Mangrove Menjadi Tambak Dan Permukiman (Studi Kasus Di Hutan Angke Kapuk Jakarta Utara). Tesis. Sekolah Pascasarjana. Institut Pertanian Bogor. Bogor.

Suzana B.O.L., Timban J., Kaunang R., dan Ahmad F., 2011. Valuasi Ekonomi Sumberdaya Hutan Mangrove Di Desa Palaes Kecamatan Likupang Barat Kabupaten Minahasa Utara. Jurnal ASE Volume 7 Nomor 2. Halaman 29-38. 